\title{
Potential of biomass energy out to 2100 , for four IPCC SRES land-use scenarios
}

\author{
Monique Hoogwijk ${ }^{\mathrm{a}, \mathrm{b}, *}$, André Faaij ${ }^{\mathrm{a}}$, Bas Eickhout ${ }^{\mathrm{b}}$, \\ Bert de Vries ${ }^{\mathrm{b}}$, Wim Turkenburg ${ }^{\mathrm{a}}$ \\ a Department of Science, Technology and Society, Copernicus Institute, Utrecht University, Heidelberglaan 23584 CS Utrecht, \\ The Netherlands \\ ${ }^{\mathrm{b}}$ Netherlands Environmental Assessment Agency (MNP), Bilthoven, The Netherlands
}

Received 24 May 2004; received in revised form 15 April 2005; accepted 10 May 2005

Available online 26 July 2005

\begin{abstract}
The availability of the resources is an important factor for high shares of biomass to penetrate the electricity, heat or liquid fuel markets. We have analysed the geographical and technical potential of energy crops for the years 2050-2100 for three land-use categories: abandoned agricultural land, low-productivity land and 'rest land', i.e. remaining noproductive land. We envisaged development paths using four scenarios resulting from different future land-use patterns that were developed by the Intergovernmental Panel on Climate Change in its Special Report on Emission Scenarios: A1, A2, B1 and B2. The geographical potential is defined as the product of the available area for energy crops and the corresponding productivity level for energy crops. The geographical potential of abandoned agricultural land is the largest contributor. For the year 2050 the geographical potential of abandoned land ranges from about 130 to $410 \mathrm{EJ} \mathrm{yr}^{-1}$. For the year 2100 it ranges from 240 to $850 \mathrm{EJ} \mathrm{yr}^{-1}$. The potential of low-productive land is negligible compared to the other categories. The rest land area is assumed to be partly available, resulting in ranges of the geographical potential from about 35 to $245 \mathrm{EJ} \mathrm{yr}^{-1}$ for the year 2050 and from about 35 to $265 \mathrm{EJ} \mathrm{yr}^{-1}$ in 2100 . At a regional level, significant potentials are found in the Former USSR, East Asia and South America. The geographical potential can be converted to transportation fuels or electricity resulting in ranges of the technical potential for fuels in the year 2050 and 2100 equal to several times the present oil consumption.
\end{abstract}

(C) 2005 Elsevier Ltd. All rights reserved.

Keywords: Potential; Global; Scenarios; Energy crops

\footnotetext{
*Corresponding author. Department of Science, Technology and Society, Copernicus Institute, Utrecht University, Heidelberglaan 23584 CS Utrecht, The Netherlands.

Tel.: + 31302537600 , fax: +31302537601 .

E-mail address: monique.hoogwijk@mnp.nl (M. Hoogwijk).
}

\section{Introduction}

Biomass has been used for energy purposes since millennia. It still is the main energy source in 
a number of countries and regions (e.g. Bhutan $86 \%$, Nepal 97\%, Asia 16\%, East Sahelian Africa $81 \%$ and Africa 39\% [1-3]). The main use of biomass energy in these countries is firewood for cooking and heating. Part of this traditional biomass use is considered to be not sustainable, as it may contribute to land degradation, sometimes even desertification. Furthermore, one of the major problems of traditional biomass use for heating and cooking is the negative impact on the indoor air quality [4].

The modern use of biomass is distinguished from the traditional use of biomass energy by its conversion into high-quality energy carriers, like electricity and biomass liquid fuels for transportation. Examples of modern biomass use are: ethanol production in Brazil from sugarcane [5], combined heat and power (CHP) district heating programs in Austria and Scandinavian countries [6], and the co-combustion of biomass in conventional coal based power plants in the Netherlands [7]. Of the total consumed biomass energy in 1998, estimated at $45 \pm 10 \mathrm{EJ} \mathrm{yr}^{-1}$, about $7 \mathrm{EJ} \mathrm{yr}^{-1}$ is considered modern biomass [6].

Modern biomass energy is expected to gain share in the future energy market, because the production and conversion costs of biomass energy are expected to be reduced, the resources are widely available and because there is an expected increase in the demand for $\mathrm{CO}_{2}$ neutral fuels. Various studies assume penetration levels of biomass in the future energy system in the order of $10 \%$ to about $50 \%$ of the total primary energy demand [8-16]. To what extent biomass will penetrate future energy markets depends on various aspects, e.g. the availability of the resources, the costs of primary biomass, the development of conversion technologies, the cost of converted biomass energy and implementation, social and/or institutional factors. Examples of the latter are installation constraints like license requirements, noxious smell and investment rates. Also of importance are the demand for energy carriers and the costs of other energy sources.

Previously, many biomass energy potential assessments have been conducted at a global scale (see [8] for an overview). However, most studies are conducted at a high aggregation level, i.e. at the level of regions. Except for the studies conducted by Fischer and Schrattenholzer [12] and Sørensen [16], the studies have not included spatial distribution of the biomass available for energy and are limited to primary biomass resources only. Furthermore, the studies are not always transparent in the procedure for calculating energy potential; they do not present insight into factors that are important for the potential. None of the studies have included a detailed link with the use of land for other activities like supply of food and timber, whereas this competition has a high influence on the potential to grow biomass for energy as was calculated by Hoogwijk et al. [17]. They have addressed these issues at a highly aggregated geographical scale (global). From their approach, it was concluded that the potential availability of primary biomass for energy is influenced by:

1. the demand for food as a function of population and diet consumed;

2. the food production system that can be adopted worldwide, taken into account the water and nutrient availability;

3. productivity of forest and energy crops;

4. (increased) use of bio-materials;

5. other competing options for land use like for nature development.

The potential assessment that integrates food demand and supply at a detailed geographical level can supply new insights in the spatial and time dynamics of the potential of biomass for energy.

The objective of this study is to assess the geographical and technical potential of biomass energy. The focus is on the geographical potential, which is assessed taking into account the use of land for other purposes, like production of food and timber. In this study, we conduct a global and regional geographical biomass energy potential assessment based on investigations at grid cell level $\left(0.5^{\circ} \times 0.5^{\circ}\right)$ integrated with the simulation of food, feed and timber demand and supply over time at grid cell level. To get a feeling for the order of magnitude, there are about 66000 onshore cells at this resolution. At the equator, one grid cell covers an area of $3025 \mathrm{~km}^{2}$. This assessment 
includes various interactions between population dynamics, technology change and the land-use pattern. The simulation is conducted over time, using a timeframe to 2100 . For the assessment of the technical potential, regional assumptions regarding the conversion efficiencies are made.

We use the integrated model to assess the global environment (IMAGE) 2.2 model as the main framework for our analysis. The IMAGE 2.1 model was used to develop the B1 marker scenario [18] of the Special Report on Emission Scenarios (SRES) scenarios for the Intergovernmental Panel on Climate Change (IPCC) [13]. The IMAGE 2.2 model was used to implement all four main SRES scenarios with more focus on the land-use system than in the IPCC report. Results and methodology are published as a CDROM [19]. The geographical and technical potential of biomass for energy is assessed in the context of the IMAGE 2.2 implementation of the four SRES scenarios that differ regarding aspects like population, GDP, social behaviour (e.g. diet, rate of self-reliance) and technology change. Given the four SRES storylines, factors like demand and supply of food and forestry products can be quantified. This output is taken as input for the analysis of the potential of biomass for energy in this study.

We start with a description of the approach and the boundaries of this study (Section 2). In Section 3 , the modelling framework and the scenarios that are used in the assessment are described. Section 4 describes the assessment of the land availability and crop productivity of energy crops. The results of the geographical potential are described in Section 5. In Section 6, the approach for the technical potential assessment is described and the results are given. The results are discussed, including a sensitivity analysis and a comparison with previous studies in Section 7. A summary and conclusions are presented in Section 8.

\section{Definitions and system boundaries}

\subsection{Categories of potentials}

We distinguish five categories of potentials using a similar division as the wind energy potential assessment study of the Utrecht University published in 1993 and 1994 [20,21].

- The theoretical (available) potential at grid cell level $\left(T_{i}\right)$ : The theoretically upper limit of primary biomass; i.e. the Net Primary Productivity of biomass produced at the total earth surface by the process of photosynthesis $\left(\mathrm{EJ} \mathrm{yr}^{-1}\right): T=A_{i} \sum_{i=1}^{n} P P P$.

- The geographical potential $G$ : The theoretical potential at land area available for the production of biomass for energy $\left(\mathrm{EJ} \mathrm{yr}^{-1}\right)$. We determine a land-claim exclusion factor at grid cell level $i(a)$ to estimate the area available for biomass production: $G=T_{i} a_{i}$.

- The technical potential at grid cell level $\left(T e_{r}\right)$ : The geographical potential reduced by losses due to the process of converting primary biomass to secondary energy carriers, defined by the conversion efficiency of the conversion technology $\left(\mathrm{EJ} \mathrm{yr}^{-1}\right): T e_{i}=G_{i} \eta_{t}$.

- The economic potential: The technical potential that can be realised at profitable levels, depicted by a cost-supply curve of secondary biomass energy $\left(\mathrm{EJ} \mathrm{yr}^{-1}\right)$.

- The implementation potential: The maximum amount of the economic potential that can be implemented within a certain timeframe, taking (institutional) constraints and incentives into account $\left(\mathrm{EJ} \mathrm{yr}^{-1}\right)$.

The estimation of the theoretical potential of biomass energy is based on productivity assumptions for energy crops. The data required for the calculation are presented in Section 4 and results are presented in Section 5. The focus of this study is, however, on the geographical potential of primary biomass energy and on the technical potential of biomass for transportation fuels or electricity. The economic potential is assessed in a subsequent paper [22].

\subsection{Description of primary biomass categories}

We only consider terrestrial options to produce biomass. One can distinguish two main categories of primary biomass: residues, e.g. forest and 
agricultural residues, and energy crops. The competition and synergism of various primary biomass sources are shown in Fig. 1. Residues or waste streams become available both at the point of harvesting and when processing food or forest crops (respectively, field and processing residues). The residues can for instance be used for fibres, fodder and fertiliser (see Fig. 1). Residue flows can also be used for energy. The final type of residues (waste) becomes available after a delay. This can be several months, and also years. Examples of biomass from dedicated energy plantations are short-rotation wood (e.g. willow, poplar or eucalyptus), sugar- or starch-containing crops (e.g. sugarcane or maize) or herbaceous grass (e.g. switchgrass or miscanthus).

\subsection{Restriction to woody energy crops}

From Fig. 1 we have seen the complexity of the competition and synergies among the various types of biomass energy sources. Including all types of sources would require a comprehensive dynamic model that simulates the food and forest demand and supply integrated with the simulation of the demand and supply of alternative applications for the produced biomass, e.g. materials, fertilisers and fodder. The IMAGE 2.2 model does not simulate material or fodder flows in such comprehensive way that synergism and competition can be studied. Models that focus more on the interaction between material flows and biomass for energy have been published by Fujino et al.

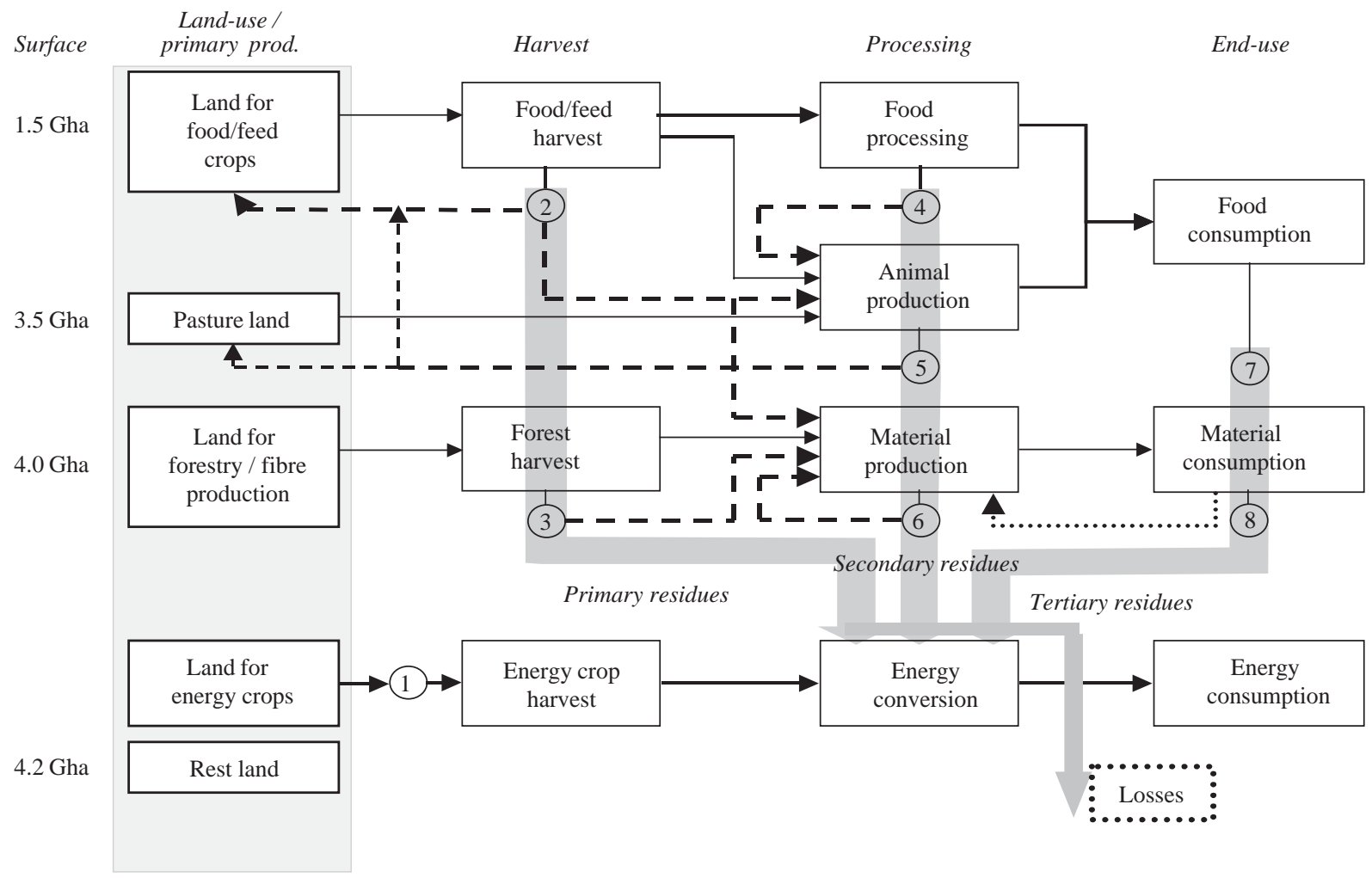

Fig. 1. Overview of various present types of biomass flows and the global land surface, based on [28,65]. The black arrows indicate the main product flows, whereas the dotted lines show potential non-energy applications of various residue categories. The thick grey arrows represent the potential energetic use of the resources (1, energy crops; 2, agricultural residues; 3, forest residues; 4, food processing residues; 5 , animal manure; 6 , material processing residues; 7 , food consumption waste; 8 , non-food consumption waste). 
[23], Gielen et al. [24] and Yamamoto et al. [25]. However, these models do not include the full dynamics of land-use integrated with food and timber demand and supply spatially explicit. Therefore, the available land for energy crop potential cannot be computed (dynamically) in relation to food and forestry demand and supply over time with the use of these models. Results of assessments of the potential of residues are shown in Table 1. Compared to traditional biomass energy use, the potential of residues is in the same order or considerably higher.

Here, we focus in more detail on the geographical potential of energy crops. A focus on energy crops is considered sensible as previous studies have concluded that the geographical potential from the residues flows is in most of the timeframe (significantly) lower than the geographical potential of the energy crops, e.g. [11,14,25,26]. Energy crops are further divided in three categories: energy crop at abandoned agricultural land, lowproductive land and at 'rest land', specified in more detail in Section 3.3.

We restrict ourselves to one energy crop category (see Fig. 1): woody biomass grown in short rotations. First of all, this is due to the fact that there is plentiful experience with shortrotation forestry for the pulp and paper industry. Furthermore, woody biomass can be converted into all types of secondary energy carriers.
Although we use woody crops to investigate the geographical potential of energy plantations at a global scale, we acknowledge that in tropical regions higher productivity levels can be expected when herbaceous crops are used [27]. The species of energy crop is not specified further in this study. It is assumed that mostly indigenous crops are used. Within the IMAGE 2.2 model productivity of energy crops is parameterised in a generic way, by assuming optimal photosynthesis efficiency (e.g. optimal water use efficiency) at grid cell level. For moderate climates a typical crop is probably willow or poplar. In more tropical climates, eucalyptus is often the most suitable perennial woody biomass crop.

\subsection{Restriction of conversion technologies}

Biomass can be converted to a number of secondary energy carriers (electricity, gaseous, liquid and solid fuels and heat) using a wide range of conversion routes. Here we focus on conversion to electricity and liquid transportation fuels, as these are large-scale options that can be considered in a generic manner. The conversion routes to fuels and electricity can be distinguished in thermal, chemical and biochemical conversion routes (see for an overview of present technologies, e.g. $[6,28])$. For the future, gasification of biomass in combination with power generation using

Table 1

Estimates from the literature on the global (geographical) potential of biomass residues for energy

\begin{tabular}{|c|c|c|c|c|c|}
\hline \multirow[t]{3}{*}{ Source } & \multirow[t]{3}{*}{ Types of residues $^{\mathrm{a}}$} & \multicolumn{4}{|c|}{ Biomass residue potentially available $\left(\mathrm{EJ} \mathrm{yr}^{-1}\right)$} \\
\hline & & \multicolumn{4}{|l|}{ Year } \\
\hline & & 1990 & $2020-2030$ & 2050 & 2100 \\
\hline [27] & $\mathrm{CR}, \mathrm{AR}$ & & 31 & & \\
\hline$[14]^{\mathrm{b}}$ & FR, CR, AR, MSW & & 30 & 38 & 46 \\
\hline [26] & FR, MSW & & 90 & & \\
\hline [67] & & & & & 272 \\
\hline [12] & FR, CR, AR, MSW & & & $217-245$ & \\
\hline [23] & & 88 & & & \\
\hline$[11]^{\mathrm{b}}$ & FR, CR, AR, MSW & & 62 & 78 & \\
\hline [63] & FR, CR, AR & & 87 & & \\
\hline
\end{tabular}

${ }^{\mathrm{a}} \mathrm{FR}$, forest residues; CR, crop residues; AR, animal residues; MSW, municipal solid waste.

${ }^{\mathrm{b}}$ These studies rather estimated the potential contribution, instead of the potential available. 
combined cycle is expected to reach high efficiency levels and lower electricity production cost and is included in this study $[6,29,30]$. Transportation fuels from biomass are at present mainly derived from sugar- or starch-containing crops (e.g. ethanol from sugar cane or maize) [5]. From lignocellulosic crops, advanced technologies are the conversion via gasification to methanol and hydrogen, the conversion to ethanol using a hydrolysis and fermentation step and the conversion to long-chain hydrocarbon fuel as Fischer-Tropsch [30-32]. In this study, we simulate the advanced fuel conversion technologies generally taking data that apply both for FischerTropsch and ethanol. These conversion technologies are presently not commercially available, however, for the long term $(\sim 2050)$, the chosen technologies are considered interesting according to their projected technology and cost developments [6,30,32-34].

\section{Methodology, framework, scenarios and main assumptions}

The geographical potential $\left(G_{i}\right)$ is defined as the amount of primary biomass that can be produced for energy purposes at available land areas. The available land is land remaining after satisfying regular demand for food and forestry products, corrected for biodiversity losses, for nature development and land required for animal grazing or physically not suitable for energy crops. The available area is distinguished in three categories (see Section 3.3). The latter competing land-use options are included in the land-claim exclusion factor $\left(a_{i}\right)$. The geographical potential of biomass from energy crops can be expressed as (see also Fig. 2)

$G_{i}=\sum_{i=1}^{n} A_{i} a_{i} Y_{i} M F$

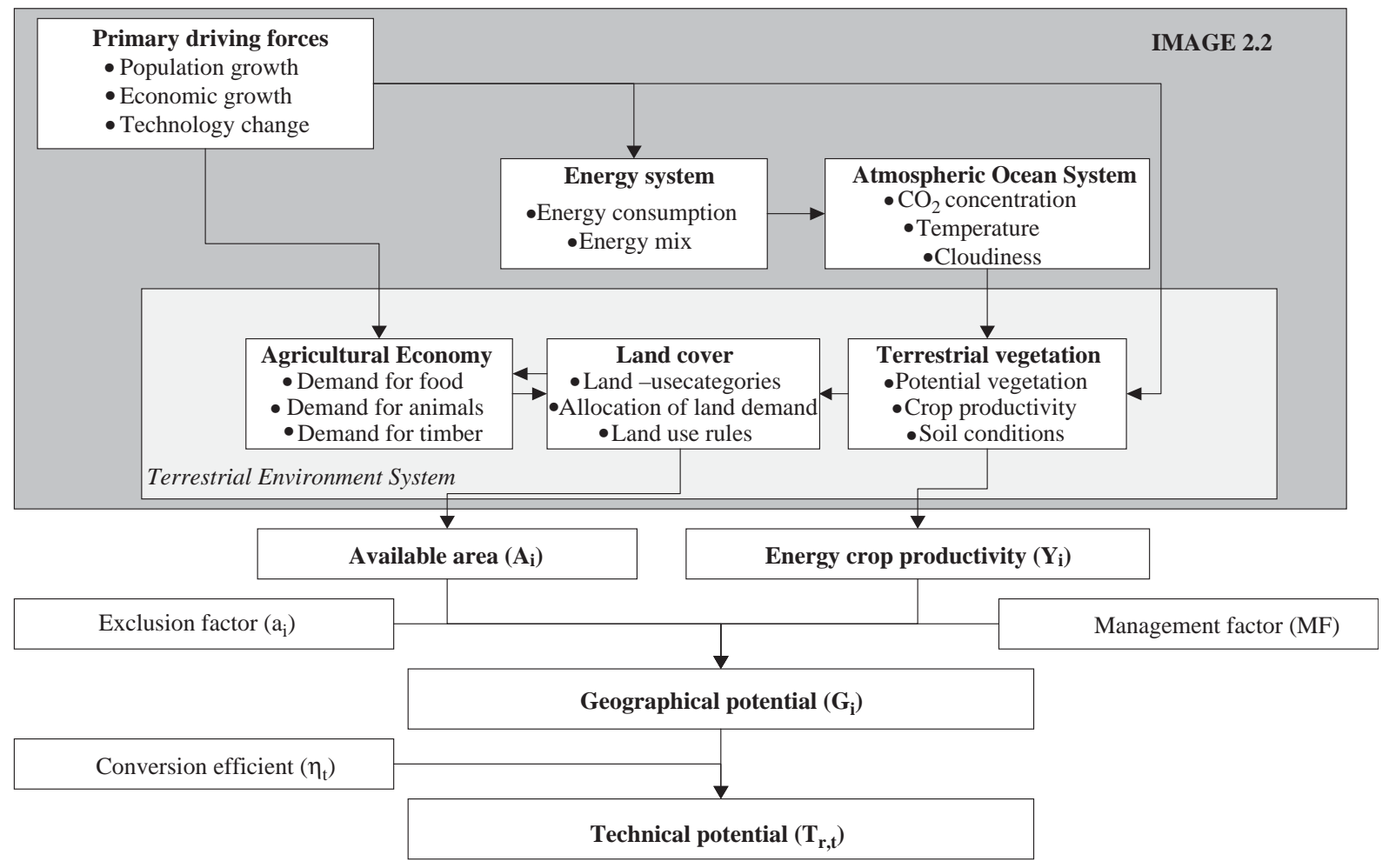

Fig. 2. Key elements for the assessment of the geographical and technical potential of energy crops using the IMAGE 2.2 model. 
In which $G_{i}$ is the geographical potential of biomass from energy crops in grid cell $i\left(\mathrm{EJ} \mathrm{yr}^{-1}\right)$; $A_{i}$ is the area in grid cell $i\left(\mathrm{~km}^{2}\right) ; a_{i}$ is the landclaim exclusion factor for energy crop production in grid cell $i(-)$ which accounts for the competing land-use options; $Y_{i}$ the harvested rainfed yield of energy crops in grid cell $i\left(\mathrm{GJ} \mathrm{ha}^{-1} \mathrm{yr}^{-1}\right)$ and MF is the management factor representing the development of the management and technology (-). This MF is similarly defined as the MF for food crops used in the Land-Cover model of IMAGE 2.2.

Fig. 2 indicates the approach to assess the geographical potential. The role of the IMAGE 2.2 model $[19,35]$ is explicitly illustrated in Fig. 2. The IMAGE 2.2 model is run to generate land-use patterns that apply for forestry demand and food demand over time. The available land for energy crops is derived from this run. Furthermore, the productivity of energy crops is simulated in the IMAGE 2.2 model. These two outcomes are combined outside the framework of the IMAGE 2.2 model to estimate the geographical and technical potential of biomass energy (see Fig. 2). The IMAGE 2.2 model, the SRES scenarios, the land-claim exclusion factor and the MF for energy crops are described below. The assumed efficiency for the assessment of the technical potential is given in Section 6.

\subsection{The IMAGE 2.2 model: the terrestrial environment system}

The objective of IMAGE 2.2 is to explore the long-term dynamics of global environmental change. The model consists of several linked modules. Within IMAGE 2.2 the world is divided in 17 regions: Canada, USA, Central America, South America, Northern Africa, Western Africa, Eastern Africa, Southern Africa, OECD Europe, Eastern Europe, Former USSR, Middle East, South Asia, East Asia, South East Asia, Oceania and Japan. As main driving forces economic and demographic trends for the 17 regions are used. Regional energy consumption, conversion of energy technological improvements, energy efficiency improvements, fuel substitution, supply and trade of fossil fuels and renewable and nuclear energy technologies determine energy production, energy use and emissions of greenhouse gases (GHGs), ozone precursors and sulphur. Ecosystem, crop and land-use modules are used to compute land use on the basis of regional consumption, production and trading of food, animal feed, fodder, grass and timber, and local climatic and soil properties. GHG emissions from land-use change, natural ecosystems and agricultural production systems and the exchange of $\mathrm{CO}_{2}$ between terrestrial ecosystems and the atmosphere are simulated. The atmospheric and ocean models calculate changes in atmospheric composition by employing the emissions and by taking oceanic $\mathrm{CO}_{2}$ uptake and atmospheric chemistry into consideration. Subsequently, changes in climatic properties are computed by resolving oceanic heat transport and changes in radiative forcing due to changing concentration of GHGs and aerosols. The impact models involve specific models for sealevel rise and land degradation risk and make use of specific features of the ecosystem and crop modules to depict impacts on vegetation.

Simulations by the IMAGE 2.2 model are conducted for the time frame 1970-2100. Historical figures (1971-1995) are used to calibrate the model. The model runs at a geographical grid cell level of $0.5^{\circ} \times 0.5^{\circ}$, longitude, latitude. A detailed description of the IMAGE 2.2 model can be found in $[19,35]$.

In this study, we use the terrestrial system of IMAGE $2.2[35,36]$ that deals with the demand and production of land-use products like food and forestry products. The terrestrial environment system (TES) is included in Fig. 2 and consists of three parts: the Agricultural Economy model, the Terrestrial Vegetation model and the Land-Cover model. The Land-Cover model of IMAGE 2.2 simulates changes in land cover on a terrestrial grid $\left(0.5^{\circ} \times 0.5^{\circ}\right)$ until regional demands for land use are satisfied. The main input to the LandCover model comes from the Agricultural Economy model and the Terrestrial Vegetation model.

The Terrestrial Vegetation part simulates the consequences of changes in atmospheric $\mathrm{CO}_{2}$ concentrations and climate on natural vegetation patterns, on the terrestrial carbon cycle, and most importantly on the crop productivity influencing the land-cover pattern. The productivities for 12 
food crops are calculated in the crop growth model of IMAGE 2.2 as presented in Fig. 3. The crop production model [37] is based on the FAO AgroEcological Zones Approach [38]. This model calculates 'constraint-free rainfed crop yields' accounting for local climate and light attenuation by the canopy of the crop considered. The climaterelated crop yields are adjusted for grid-specific conditions by a soil factor with values ranging from 0.1 to 1.0 . This soil factor takes into account three soil quality indicators: (1) nutrient retention and availability; (2) level of salinity, alkalinity and toxicity; and (3) rooting conditions for plants. The crop growth model is calibrated using historical productivity figures.

The Land-Cover part simulates the spatial changes in land-cover transformation by reconciling the demands for land-use products (from the Agricultural Economy part) with the potential of land (from the Terrestrial Vegetation part). It differentiates 19 land-cover types and allocates these land-cover types over the global terrestrial surface. The land-use types distinguished in the IMAGE 2.2 model are: Agricultural land; Extensive grassland; Tundra; Temperate deciduous forest; Savannah; Wooded tundra; Warm mixed forest; Tropical woodland; Boreal forest; Grassland and steppe; Tropical forest; Cool coniferous forest; Hot desert; Temperate mixed forest; Scrubland; Ice; Regrowth forest (abandoning); Regrowth forest (timber). A key aspect of the Land-Cover model is that it uses a crop- and regionally specific MF to represent the gap between the theoretically feasible crop yields simulated by the Terrestrial Vegetation model, and the actual crop yield which is limited by less than optimal management practices, technology and know-how. If nutrients are applied optimally, there is sufficient weeding at the plantation and the harvest is optimal, the MF reaches a value of 1 . Irrigation, improvement in the harvest index (see Fig. 3) and biotechnological developments can increase the MF further to values above 1 . Regional MFs are used to calibrate the model to

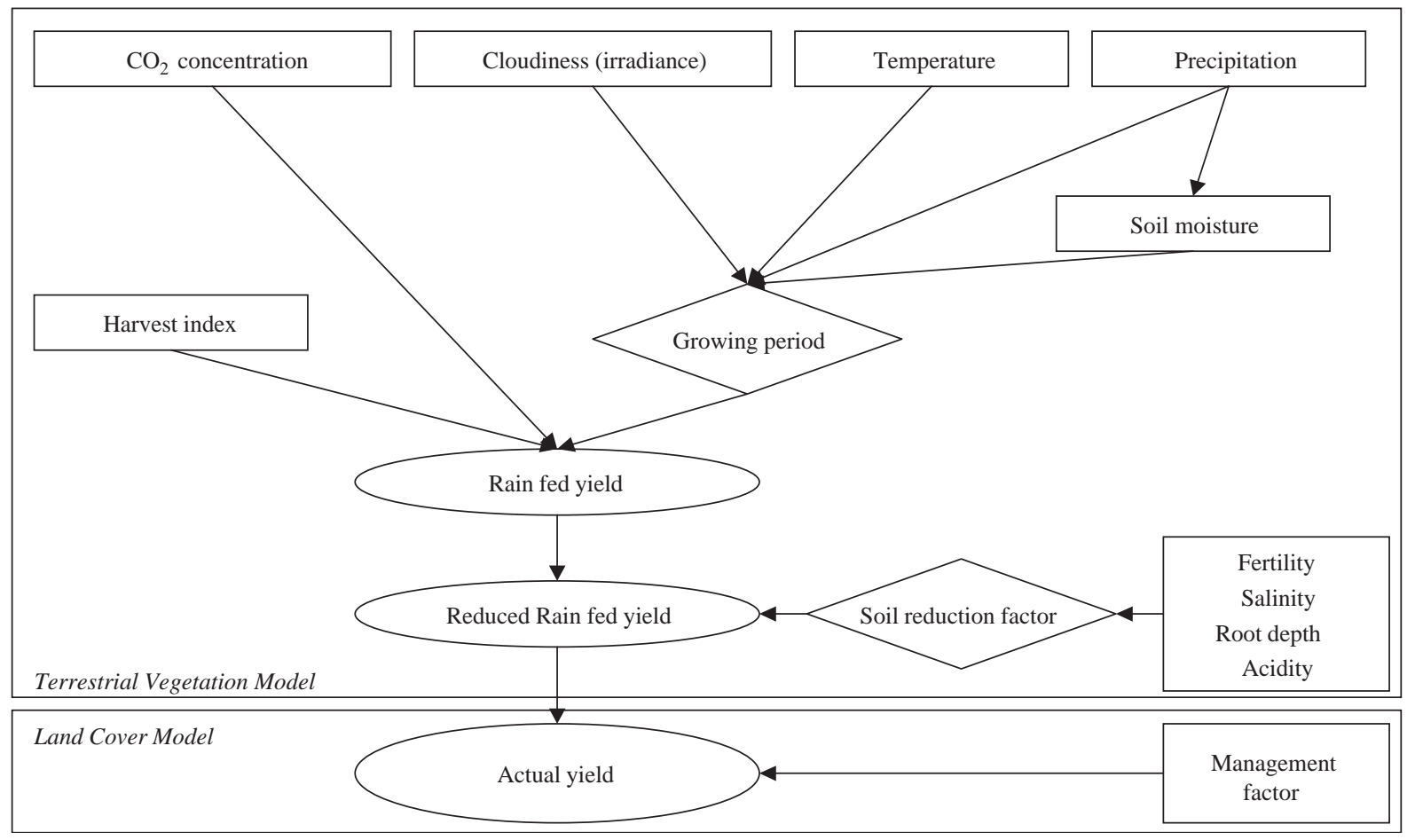

Fig. 3. Schematic representation of the simulation of land productivity within the IMAGE 2.2 model, based on [37]. 
regional estimates of crop yields and land cover for the period 1970-1995 from FAO [39]. For years after 1995 the MF is a scenario variable.

The allocation of land-use types is done at grid cell level. Among these land-cover types are agricultural land and forest areas. Land-use transformations are in reality influenced by social, physical and economic forces. These forces are too complex to be integrated in a dynamic way in the IMAGE 2.2 model. As a proxy, the allocation of land-use types in the IMAGE 2.2 model is based on several criteria or logical rules. These are considered as simplifications of the complexity of the real forces that can be encountered due to the demand and supply of land. The LandCover model explicitly deals with four land-cover transitions:

1. natural vegetation to agricultural land (either cropland or pasture) because of the need for additional agricultural land;

2. agricultural land to other land-cover types because of the abandonment or unsuitability (under climate change) of agricultural land;

3. forests to 'regrowth forests' because of timber and fuelwood extraction;

4. one type of natural vegetation to another because of climate change and/or increased water use efficiency.

The food or feed crops are allocated to grid cells of the type agricultural land. In each grid cell, various types of crops can be allocated, with preference to the productivity levels. The specific crops are allocated within the agricultural cell according to their crop productivity [35]. The Land-Cover model results in land-cover allocation of all 19 land-cover types at grid cell level.

\subsection{The quantification of the SRES scenarios of the IPCC}

The assessment of the geographical potential of biomass for energy is conducted within the context of four different storylines for the development of the society. We have chosen to use four storylines published by the IPCC in the SRES [13] as implemented with the IMAGE 2.2 model [19].
The storylines describe different social, economic, technological, environmental and policy developments. Basically the four storylines are constructed along two dimensions, i.e. the degree of globalisation versus regionalisation, and the degree of orientation on material versus social and ecological values (see Fig. 4). The four scenarios do not have a particular order and are listed alphabetically and numerically, i.e. A1, A2, B1 and B2. We use the parameters of the Alb scenario (see [13]). Fig. 4 shows the most important assumptions regarding food demand and supply made in each scenario.

In Fig. 5, the demand for food over time on a daily per capita basis used in the SRES scenarios is compared with figures from other sources $[19,40-44]$. The values found in these literature sources range widely, up to $35 \%$. The variation between the scenarios is less significant, about $6 \%$. Food intake assumed in our scenarios does not exceed the boundary levels found in the literature. This intake is assumed to increase about $20 \%$ (A2) to $28 \%$ (B1 and $\mathrm{A} 1)$ over the 100 -year period.

\subsection{Land availability $\left(A_{i}\right)$ : different categories of land for energy plantations}

At present many short-rotation energy forestry projects are - or are expected to be-implemented on land not required (anymore) for food. This can be degraded land or abandoned agricultural land [45-48]. Furthermore, there are assessments of short-rotation forestry on savannah land [49]. In this study, we distinguish three categories of land available for energy plantations: (1) abandoned agricultural land; (2) low-productive land and (3) 'rest land' which is the remaining area further corrected for the grassland area, the forest land, the urban area and the bioreserves. This 'rest land' includes mainly savannah, shrubland and grassland/steppe. These categories are based on the assumption that the production of energy crops should not effect food and forestry production, nature reserves or biodiversity and animal grazing. Furthermore, tundra area is excluded as it is considered to be unsuitable for energy crop production. Dessert areas are not excluded, however 


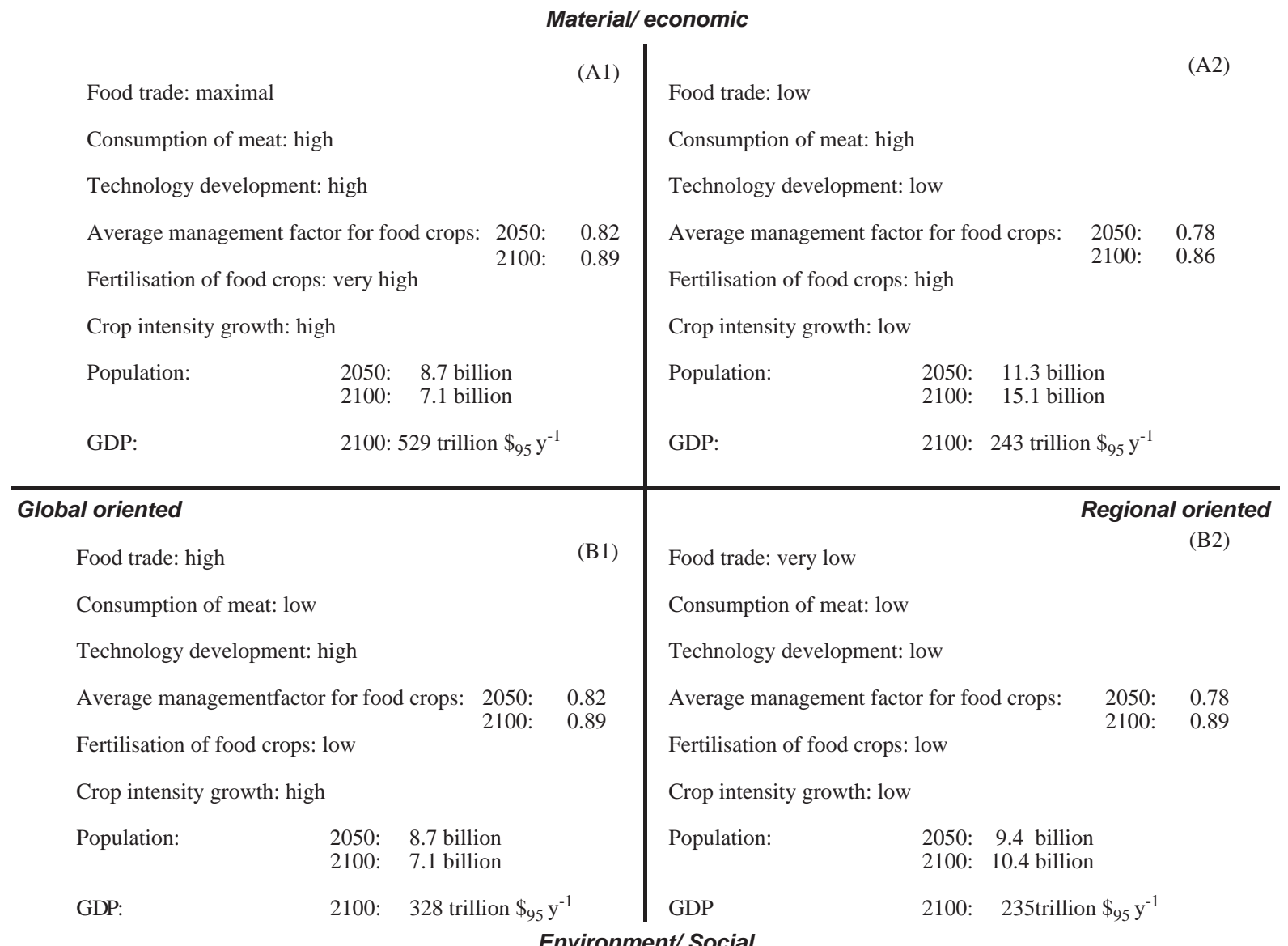

Fig. 4. Assumptions related to food demand and supply for the four scenarios considered in this study.

as land productivity is about zero, it is not visible in the overall outcomes.

To determine the geographical potential, IMAGE 2.2 is first run over time for the four SRES scenarios. In these runs, the demand and production of food and forestry products are determined (see also Fig. 2). The land available per category described above is taken from this run:

(1) If within a scenario a grid cell is converted from agricultural land to natural vegetation in IMAGE 2.2-agricultural land is abandoned-it is labelled 'abandoned' and assumed to be excluded from food production. This amount is added to a pool of abandoned agricultural land area for the rest of the timeframe (2100). Agricultural land can be abandoned because of surplus cropland or because of a decrease in suitability of the soil due to climate change.

(2) We have assumed that low-productive areas have a productivity of energy crops below $3 \mathrm{tha}^{-1} \mathrm{yr}^{-1}$; about $5 \%$ of the maximum yield. ${ }^{1}$ Before we include the area, we check if this area is not used for agricultural land in the IMAGE 2.2 model.

(3) The final category is the area 'rest land' which includes the remaining land, excluding forest areas, bioreserves tundra and agricultural land.

\footnotetext{
${ }^{1}$ The maximum yield of woody biomass is set in IMAGE 2.2 at $55.8 \mathrm{tha}^{-1} \mathrm{yr}^{-1}$ based on optimal photosynthesis and respiration of the crop.
} 


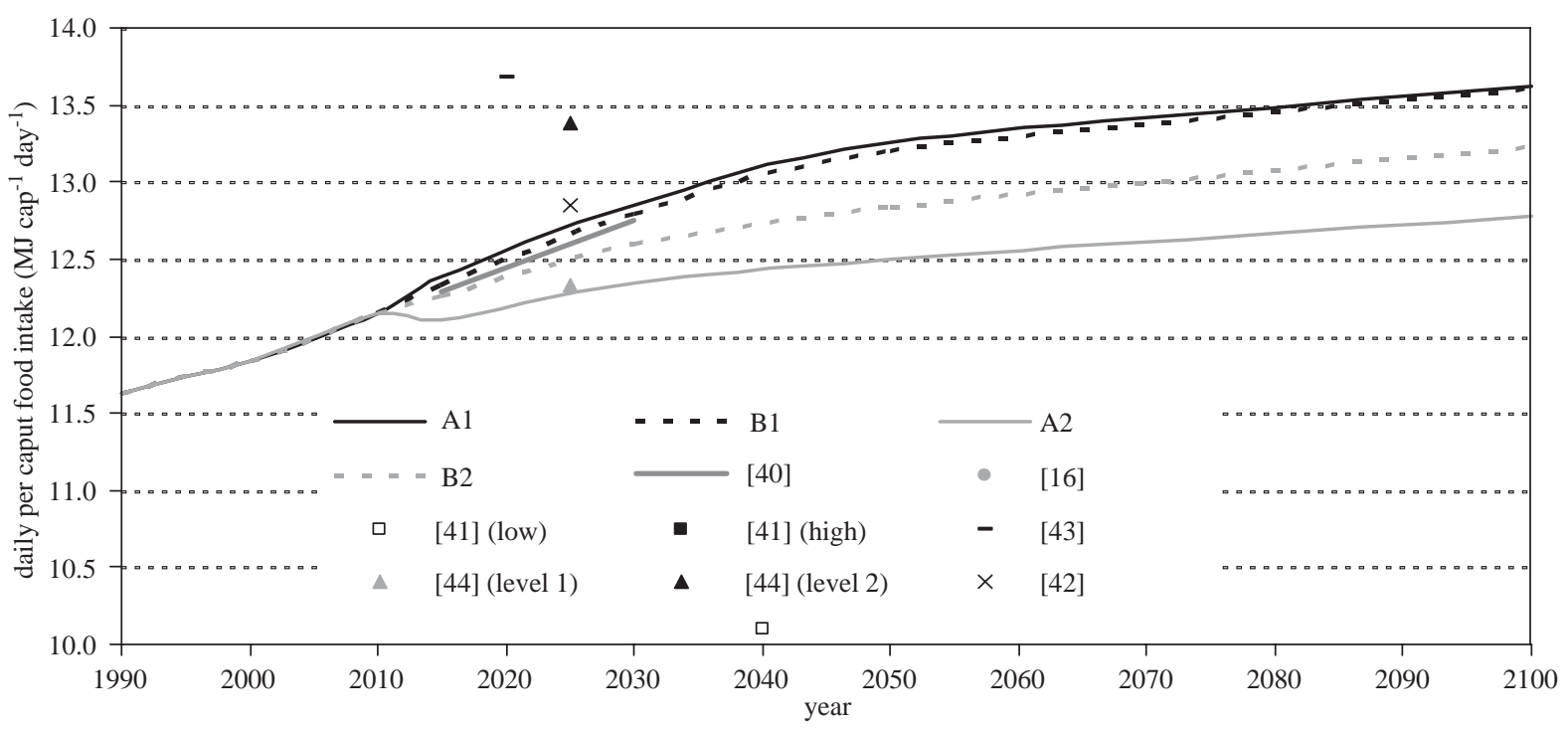

Fig. 5. Estimates of the daily caloric food intake per capita over time used in this study compared with values suggested in the literature.

\subsection{The land-claim exclusion factor}

Another factor determining the geographical potential, next to land availability is the land-claim exclusion factor $\left(a_{i}\right.$ in Eq. (1)). This factor indicates the percentage of land not available for biomass energy production. It is difficult to quantify the exclusion factor, as the empirical basis for various competing land-use options is weak, in addition these factors are judged differently for the four scenarios. We have chosen to correct for the claims for which quantification was found in literature. We exclude land-use claims for (a) nature development and (b) urbanisation; we introduce land-use specific exclusion factors as a reduction factor for (c) cattle grazing on extensive grassland. Furthermore, (d) we correct for remaining factors that are valid at rest land, like biodiversity and water resource distortion, losses of areas for nomads, etc. The consequences of this factor are addressed in the discussion.

\subsubsection{Nature development}

At present, the amount of protected areas worldwide is almost $10 \%$ of the global terrestrial area $[50,51]$. The nature reserves included in the
IMAGE 2.2 model amount $6 \%$ of the global terrestrial land area. There are initiatives to extend the protected areas, e.g. via the establishment of a global network of protected areas. This would link various isolated areas to improve the vitality of the ecosystem [50]. At a global level the area required for nature conservation is assessed to be in the range of $10-20 \%$ of the world's land area [52]. This means an increase of $0-10 \%$ compared to the present protected areas and an increase of about $5-15 \%$ compared to the values included in the IMAGE model at $6 \%$. We assume $5 \%$ for the more economically oriented scenarios (A1 and A2) and $15 \%$ for the more ecologically oriented scenarios (B1 and B2). It is furthermore assumed that nature development occurs on each land-use category.

\subsubsection{Urbanisation}

The built environment is at present about $2 \%$ of the global land area. Future increases are expected because of urbanisation and population growth [53]. The built environment has been simulated in the Global Environmental Outlook [54]. Results show figures of the built environment in the year 2030 ranging between $3 \%$ and $4 \%$ of the world's 
land area, with the highest levels in the developing regions [54]. We use these data from the Global Environmental Outlook at a regional level and assume a change of the built environment as a linear function of the population growth at a regional scale. Urban areas are assumed to be established at the land-use categories also available for biomass energy crops.

In Fig. 6, land-claim exclusion factors for urbanisation and nature development per region and scenario are given. It can be seen that the highest exclusion factor is found for South and
East Asia (India and China) due to high estimates for land required for urbanisation. The lowest exclusion factor is found for the Canada and Japan.

For the land-use specific exclusion factors following assumptions are made:

\subsubsection{Cattle grazing on extensive grassland}

Thus far, pasture areas have been far kept out of the analysis (included in agricultural land), as it is assumed that these areas are required for feed and cattle grazing. In the IMAGE 2.2 model, extensive
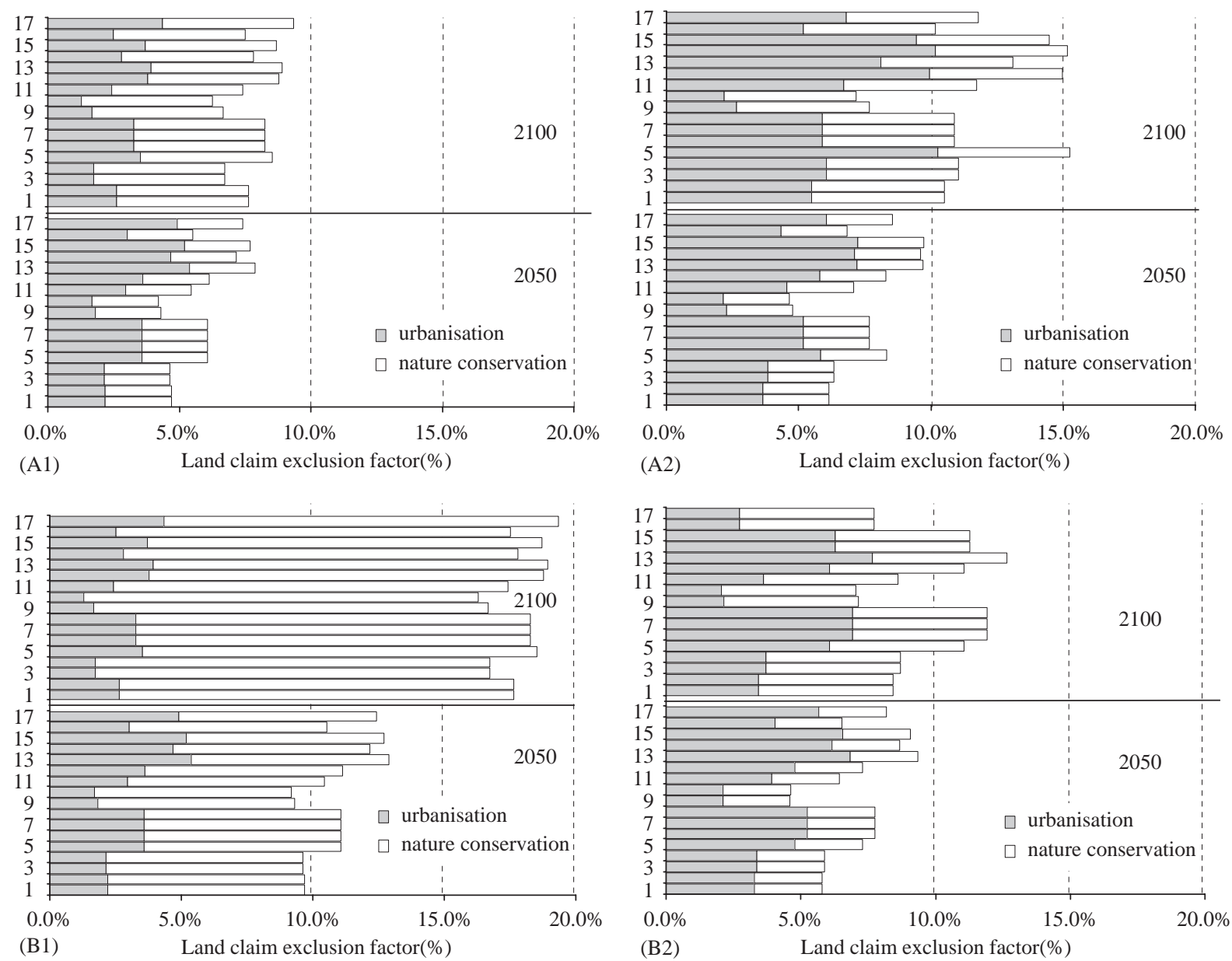

Fig. 6. Estimated land-claim exclusion factor per region and scenario. These exclusion factors apply for all land-use types suitable for energy crops (1, Canada; 2, USA; 3, Central America; 4, South America; 5, Northern Africa; 6, Western Africa; 7, Eastern Africa; 8, Southern Africa; 9, OECD Europe; 10, Eastern Europe; 11, Former USSR; 12, Middle East; 13, South Asia; 14, East Asia; 15, South East Asia; 16, Oceania; 17, Japan). 
grassland is also expected to be used for cattle grazing. The share is not further specified. The extensive grassland is included in the low-productive land category as well as in the rest land category. We use the results of Bouwman et al. [55] for the exclusion of the extensive grassland area required for cattle grazing. In their analysis, they estimate the required area for grazing in different land-use categories based on FAO data [56] At a regional level, this results in an exclusion of all extensive grassland areas (OECD Europe, South Asia and Japan) to barely any exclusion of extensive grassland (Canada, USA, Central and South America, West and South Africa, East Europe and Oceania), in the other regions. Extensive grasslands are available for biomass production for $60-65 \%$ (North and East Africa, Former USSR and South East Asia) and 39\% in East Asia and 17\% in the Middle East.

\subsubsection{Remaining exclusion factor for rest land}

We have corrected the estimated available land for energy crops for nature development, urban area and animal grazing. However, it is expected that energy crops at the 'rest land' category have larger impact on vulnerable ecosystems and water resources and encounter more competing factors that limit the complete use of the area, like recreation and land required for indigenous population. The value of these land-claim exclusion factors is conceptually difficult to quantify because it cannot be measured, depends on personal values and is not generic over the world or the regions. The value is therefore to a large extent arbitrary. We propose scenario-dependent factors as the impact on biodiversity or water availability would be judged differently among the scenarios. A more stringent factor of $90 \%$ exclusion is proposed for the more ecological oriented scenarios (B1 and B2) and a land-claim exclusion factor of $50 \%$ is proposed for the more economically oriented scenarios (A1 and A2). We will address this factor in the discussion.

\subsubsection{The management factor for energy crops}

The productivity of energy crops is a function of environmental conditions like soil quality, water balance and growing season, which in turn are dependent on climate conditions like temperature, precipitation and cloudiness. The rainfed productivity of energy crops is simulated in the IMAGE 2.2 model at grid cell level, shown in Figs. 2 and 3. The technological improvement related to woody energy crops, like the use of fertilisations, is included in the MF, shown in Figs. 2 and 3 and incorporated by calculations outside the IMAGE 2.2 model (see Fig. 2). Exogenously, the productivity can be improved in three ways: by an improvement of the photosynthetic efficiency (e.g. increasing the leaf area index), improvement of the harvest index (e.g. the ratio of the total produced biomass and the harvested part), see Fig. 3 and improvement of agricultural organisation and agricultural technology [57]. Vleeshouwers [57] expects therefore that major improvements are to come from better management. In the literature, annual increases for global average yields for the time frame up to 2020 are estimated at about $1.1-2.6 \%$ and up to 2050 at about $1.2-1.6 \%$ [57]. For comparison, the global average annual increase from 1961 to 2002 for sugarcane, wheat, rice and coffee are, respectively, $0.66 \%, 2.26 \%, 1.82 \%$ and $0.94 \%$ [39]. The average global MF for woody biomass for the year 1995 was derived from the MF of sugar cane assumed at 0.7 in the IMAGE 2.2 model. The assumed harvest index is 0.6 , which is relatively low, compared to empirical values (e.g. [58]). The maximum average value of the MF for agricultural crops in the IMAGE 2.2 model is about 1.3 for rice and maize for the B1 and A1 scenarios. Here, it is assumed that in the A1 scenario the technological development increases rapidly and also biotechnological developments are expected. We assume an upper limit of the MF of 1.5 in this scenario and an annual growth of $1.6 \%$, which is the upper growth level assumed by Vleeshouwers [57]. The maximum MF is reached in 2050. The $\mathrm{B} 1$ scenario is expected to reach levels that are lower as biotechnology is assumed to be less approved in this scenario. The upper level of the MF is therefore assumed at 1.3. The growth rate is also assumed at $1.6 \%$. For the B2 and A2 scenario, the technological development is expected to be less strong. We assume an upper level of the MF of 1.1 and a growth rate of $1.2 \%$, corresponding to the lowest growth rate found by Vleeshouwers [57]. 


\section{Results for land availability and energy crop productivity}

\subsection{Land availability}

The results of the variation in the landuse pattern based on IMAGE 2.2 runs is given in Fig. 7.

\subsubsection{Category 1: development of abandoned agricultural land}

In all scenarios, agricultural land is taken out of production, either because there is a surplus of agricultural land, or because of a decreased suitability due to climate change of land for food production. The abandoned agricultural land area is the highest in the B1 and A1 scenarios, mainly due to surplus agricultural land. In these scenarios, population reaches its maximum in 2050 and technological advancement is assumed to increase relatively fast because of a high interchange of knowledge in the globalised world. The main difference between $\mathrm{A} 1$ and $\mathrm{B} 1$ is the higher meat consumption in A1 compared to B1 (about 16\% points higher in A1 on a daily per capita basis in the year 2100), leading to slightly less abandoned land $(2 \%$ in 2100$)$. The high population growth and slow technological improvement in the A2 scenario clearly results in the lowest estimate of available abandoned agricultural land.

\subsubsection{Category 2: development of low-productive land}

The area of low-productive land is at least in the first half of the century much larger than the area of abandoned agricultural land. Most areas are extensive grassland and desert. Parts of these desert areas have very low productivity, down to zero. The extensive grassland is partly used for cattle grazing (see Section 3.4). The amount of
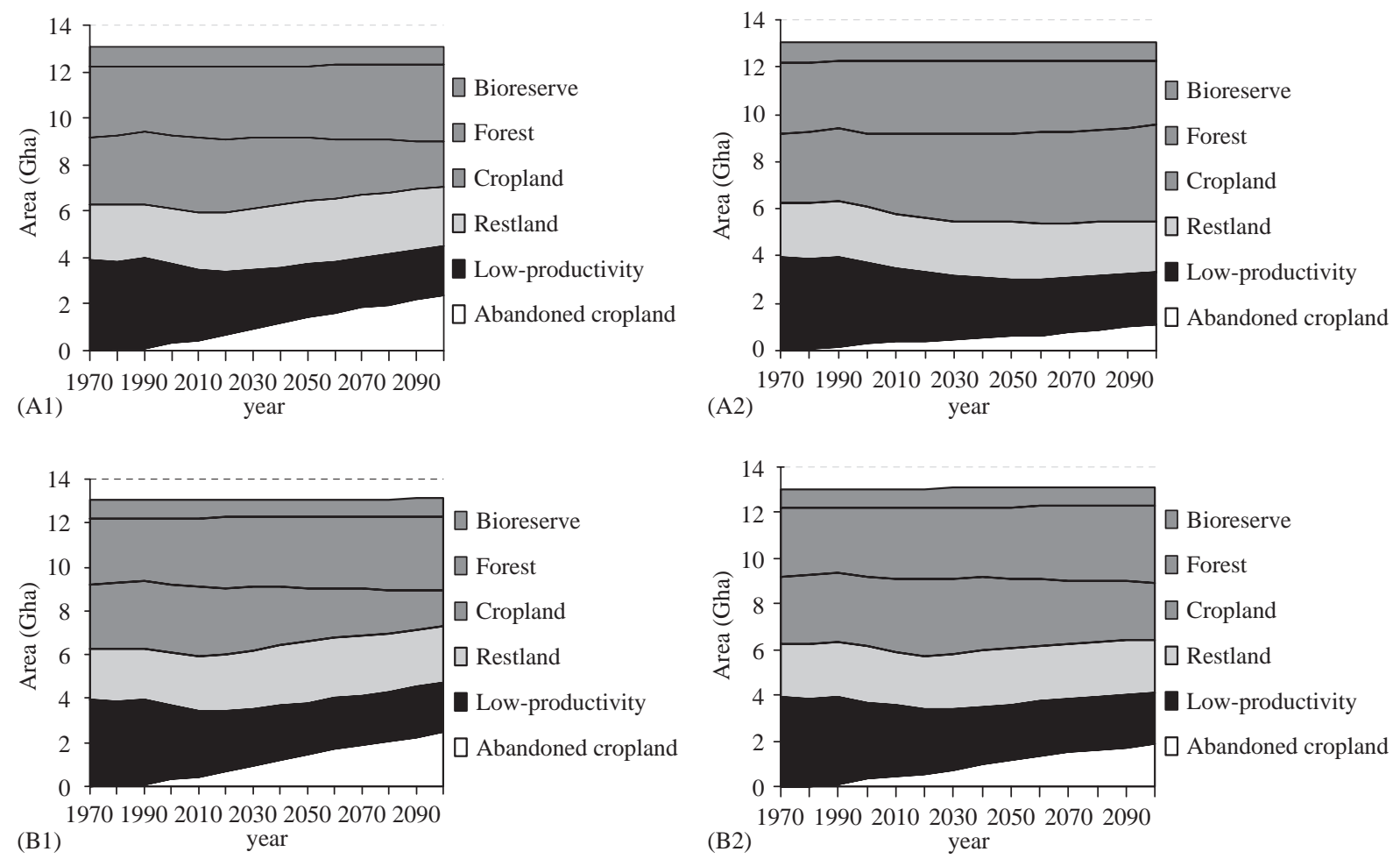

Fig. 7. Simulated distribution of the land-use pattern, excluding the land-claim exclusion factor: agricultural land, forest land, grassland, low-productive land and rest land. 
low-productive land marginally decreases over time due to the increase in productivity as a result of the technological improvements (MF) and of positive climate change feedbacks, e.g. by means of higher temperature and rainfall.

\subsubsection{Category 3: development of rest land}

As can be seen from Fig. 7, the category rest land, including savannah, extensive grassland, shrubland and (in this figure also tundra land), is significant, amounting to about 2.5 Gha in the year 2000. The rest land category varies slightly over time. It increases slightly in the first half of the century and decreases slightly in the second half. Rest land can increase because low-productive land decreases in productivity and adds to the rest land category and tundra and savannah land is converted to forest area.

Summarising, the area from abandoned agricultural land in 2050 ranges between $10 \%$ of the total land surface in the case of A1 (1.3 Gha) and 4\% (about $0.6 \mathrm{Gha}$ ) in the case of A2. For the year 2100 , these areas are about doubled in all scenarios. The total rest land area is larger, in the year 2050 around $2.3 \mathrm{Gha}$ for the three scenarios, or about $18 \%$ of the total global area. To get a feeling for the required area, we pictured the land-use pattern in the year 2050 of the world presenting these three areas in Fig. 8 for four scenarios: A1, A2, B1 and B2.

In the A2 scenario, significant amount of forest area is cut down for the production of food or fodder (see Fig. 9). This does not occur in the other scenarios due to a lower demand for food and a higher food crop MF compared to A2. As the abandoned agricultural land is assumed not to become available for agricultural or forest purposes after the area is abandoned, lost forest areas cannot be compensated for. The forest areas in the Middle East and Southern Africa completely disappear. The forest area in South America reduces significantly; about $45 \%$ in 100 years. It is noted, however, that forest area is also reduced significantly in the default run, where abandoned agricultural area can be converted to forest land (Fig. 9). The forest areas in the Former USSR, Canada and Europe (East and OECD Europe) remain almost constant over time, which means that according to the IMAGE 2.2 simulations, the pressure on the land-use system, specifically forests does not increase significant in these regions. This should be seen in the context that in the A2 scenario the regions in Africa and South America have low shares of available abandoned cropland, as most abandoned cropland is found in the northern regions as OECD Europe, the Former USSR and the USA (see Fig. 8).

\subsection{The productivity of energy crops}

The productivity of energy crops for several land-use categories (land-claim exclusion factor is not applied) is shown in Fig. 10. It is obvious that agricultural land results in overall higher productivity than low-productive land and for the major part also than rest land, as shown in Fig. 10.

The distribution of energy crop productivity over the globe (including agricultural land and forest areas) - as simulated by the IMAGE 2.2 model - is shown in Fig. 11 for two scenarios: A1 and $\mathrm{B} 2$. The A1 scenario is chosen as it provides the highest productivity level and the B2 scenario as it provides the lowest one. The figure shows also the impact of $\mathrm{CO}_{2}$ fertilisation in these scenarios on energy crop productivity as this is included in the IMAGE 2.2 model. For the current situation, the two scenarios are identical. For the future situation productivity is simulated to increase significantly, although different for the two scenarios, mainly because of different assumptions regarding productivity improvement due to an improved management of the energy crop production system. The $\mathrm{CO}_{2}$ fertilisation effect contributes only marginally.

\section{Results for the theoretical and geographical potential}

The results of the geographical potential are presented for all three categories of energy crops; however, we will elaborate mostly on energy crops at abandoned agricultural land. 


\subsection{The theoretical potential of biomass energy}

The theoretical potential of biomass energy is assumed to equal the total amount of energy crops at the total land surface. Hence, the theoretical potential for the situation in 2050 of biomass for energy is taken from Fig. 11. Using these data, the theoretical potential of biomass energy at the total terrestrial surface is about $3500 \mathrm{EJ} \mathrm{yr}^{-1}$. This is in agreement with the figure given by Hall et al. [27], of about $3300 \mathrm{EJ} \mathrm{yr}^{-1}$, assuming a lower heating value of $15 \mathrm{GJ} \mathrm{t}^{-1}$.

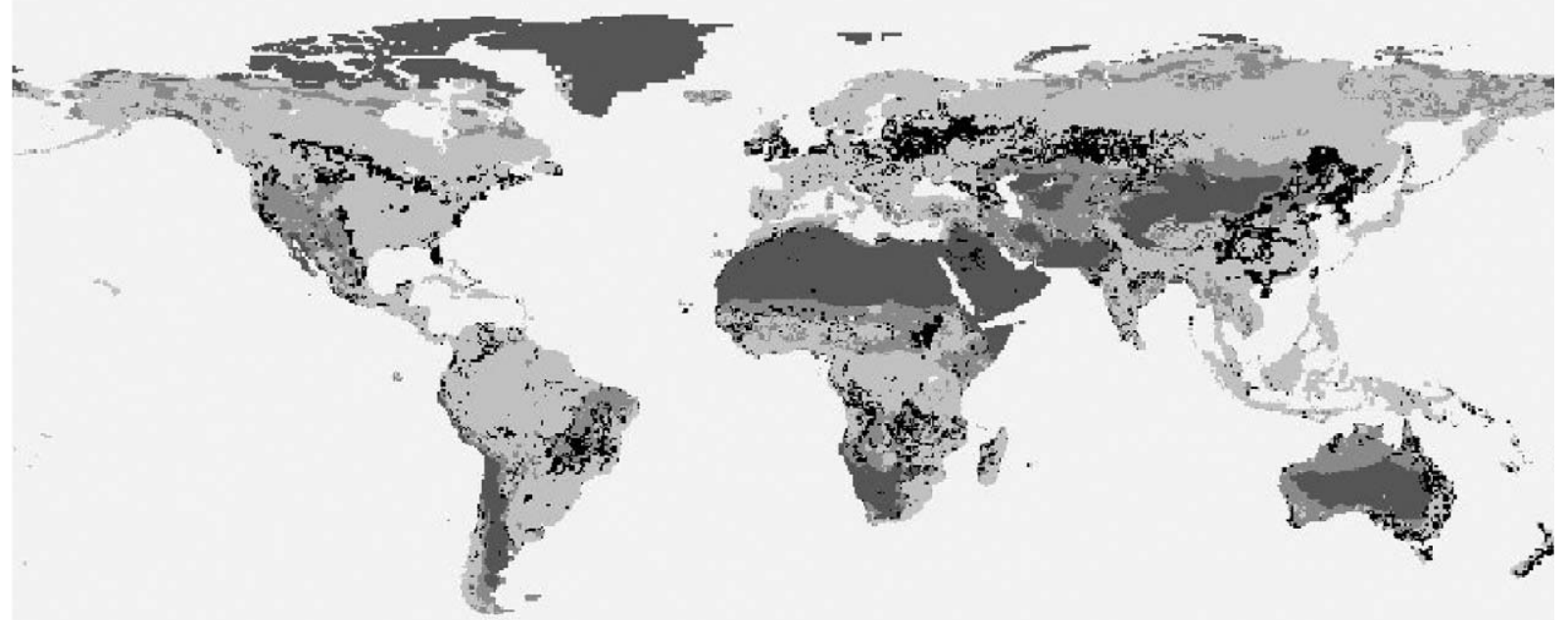

(A1)

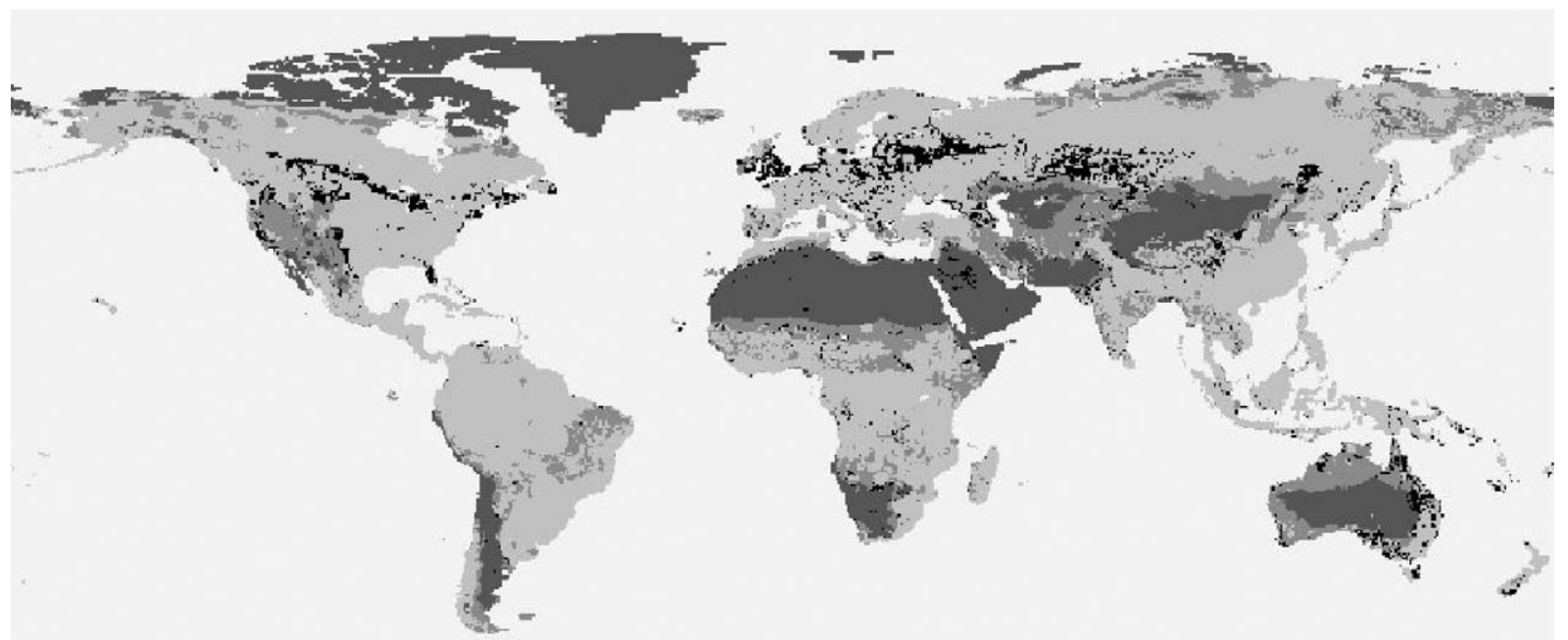

(A2)

Fig. 8. Spatial distribution of the potentially available areas for energy crop as distinguished in this study: abandoned agricultural land, degraded land and rest land, for the A1, A2, B1 and B2 scenarios for the year 2050. 


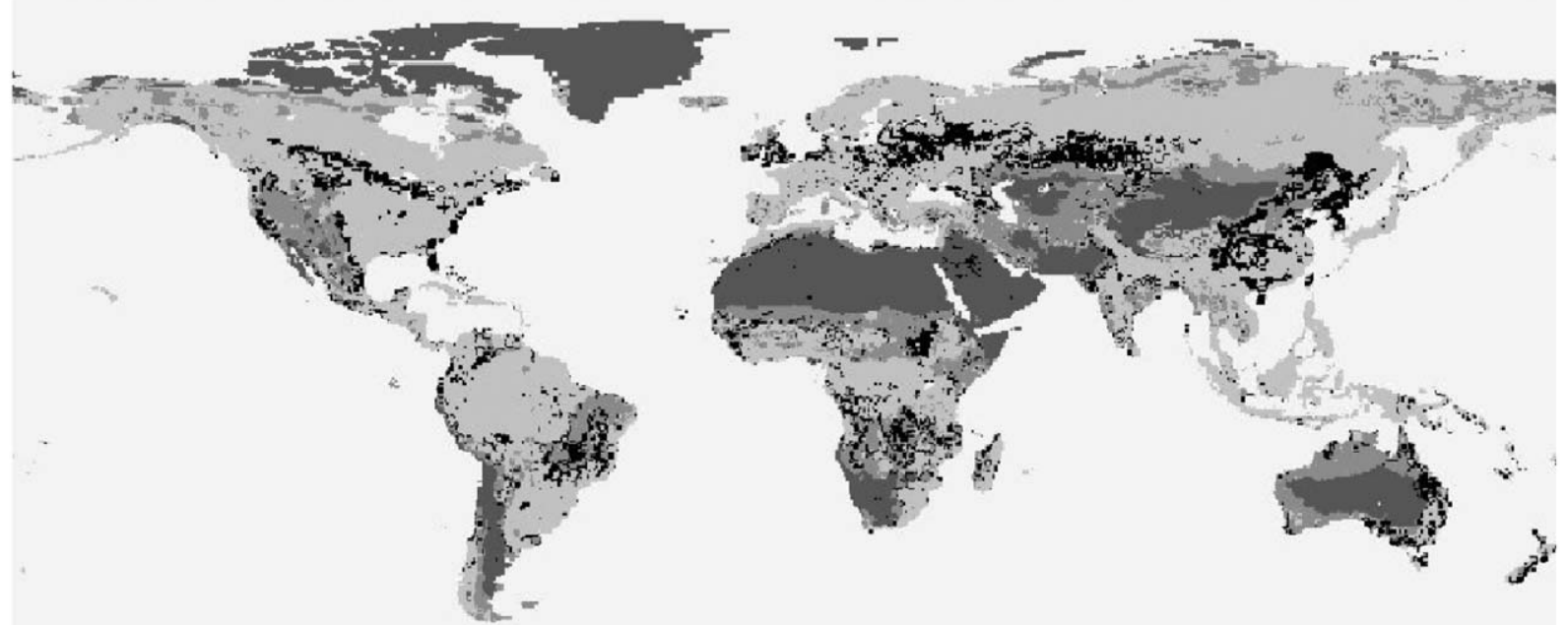

(B1)

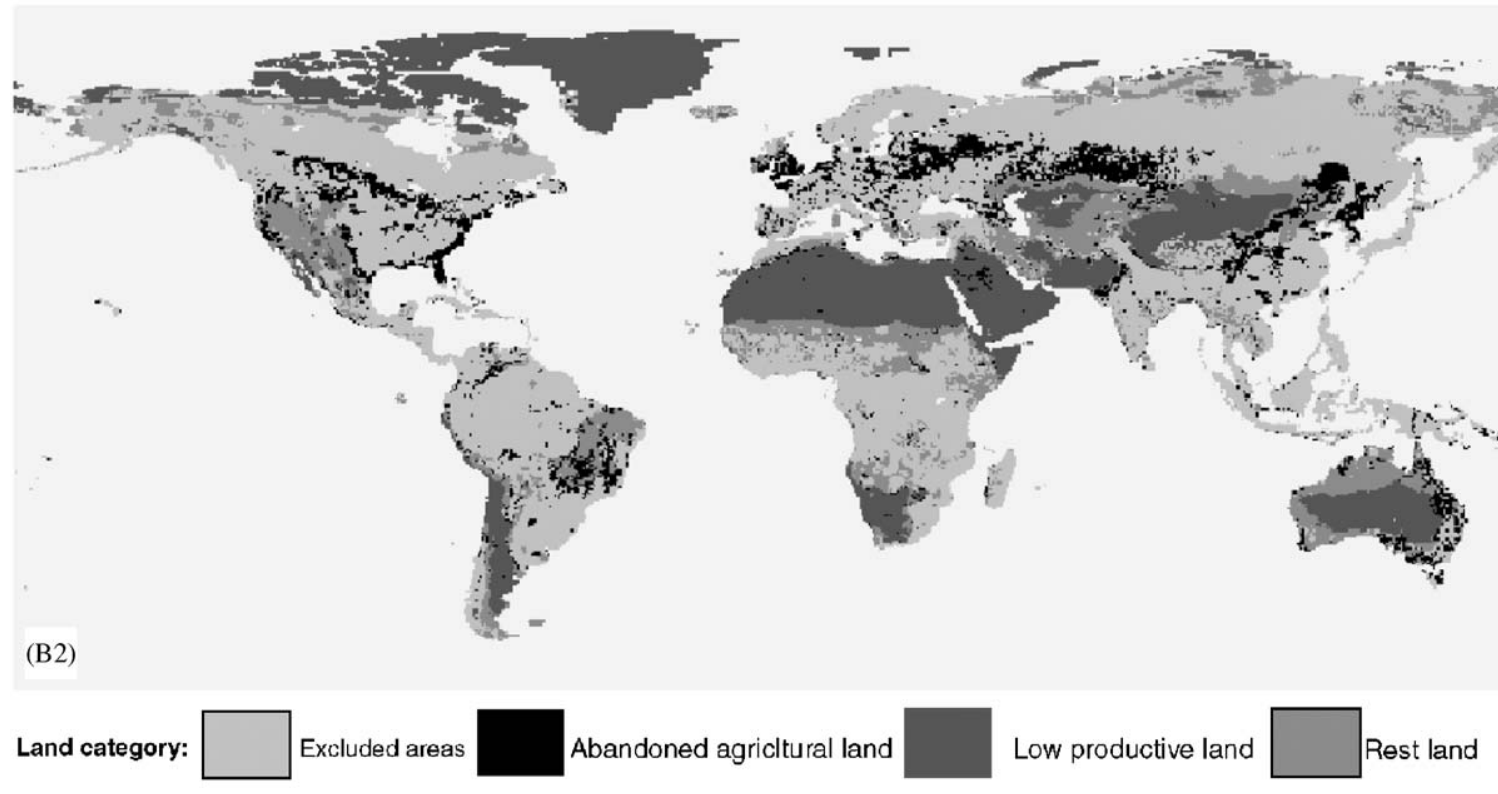

Fig. 8. (Continued)

\subsection{The global geographical potential of energy crops}

For the year 2050 and 2100, the geographical potential of growing biomass for energy purposes is given in Table 2 for each land-use type (abandoned agricultural land, low-productive land and rest land). The geographical potential of abandoned agricultural land is most significant. For the year 2050 the estimates of the geographical potential of energy crops at abandoned agricultural land for the A1 and B1 scenarios are in the same 

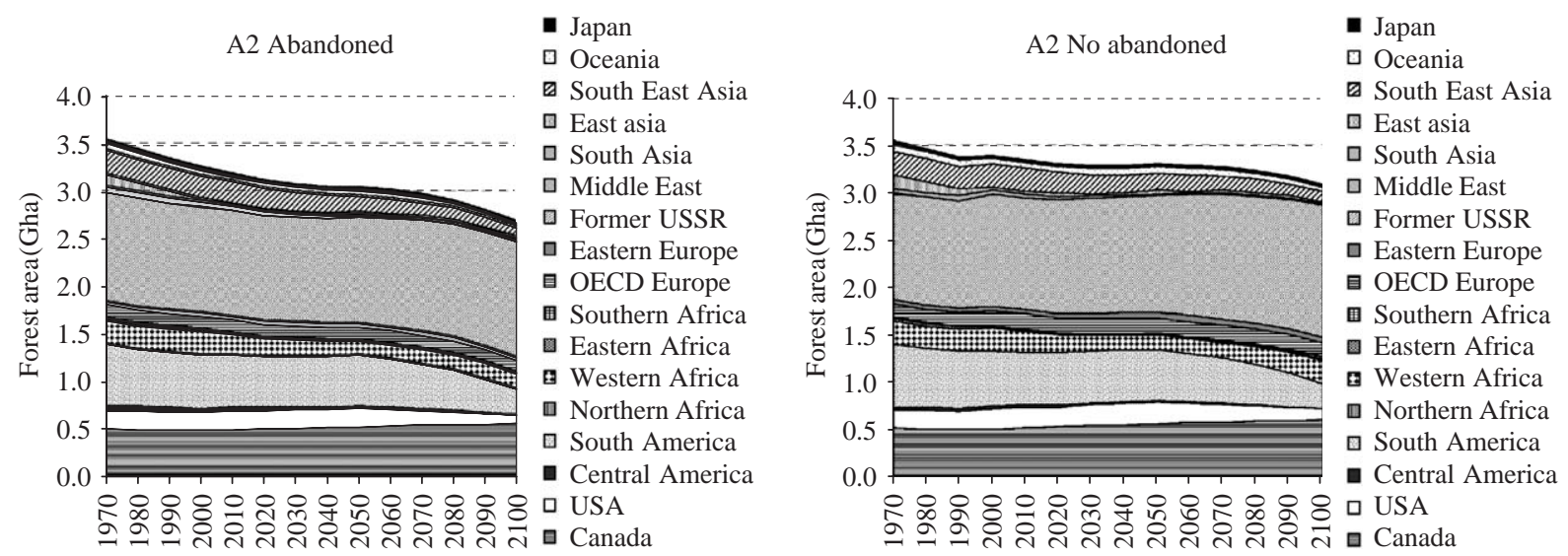

Fig. 9. Forest area development over time as simulated by the IMAGE 2.2 model for the A2 scenario with and without the inclusion of abandoned agricultural land for energy plantation.

order as the current (2000) global primary energy consumption $\left(\sim 400-450 \mathrm{EJ} \mathrm{yr}^{-1}\right)$ [59]. These even increase further in the second half of the century. Different figures are found for the A2 and B2 scenarios that result in significantly lower potentials of energy crops. The geographical potential of low-productive land is almost negligible compared to the other two categories. The potential of rest land is however significant (see Table 2). This is mainly due to savannah areas at which high land productivities are found.

The development over time of the geographical potential as sum of the three categories is shown in Fig. 12 for each scenario. The figure also shows the total simulated primary energy demand over time for the scenarios [19]. The estimated geographical potential of B1 in 2100 is higher than the simulated total primary energy demand for that scenario. The A2 scenario is the scenario with the highest total energy demand and the lowest biomass energy geographical potential. If we consider the share of biomass in the total energy mixture, this would always be limited (22\%) in an A2 world, but may reach $100 \%$ in a $\mathrm{B} 1$ scenario at the end of the century.

\subsection{Regional variation in geographical potential}

Which regions have the highest geographical potential for energy crop production? Table 2 shows the geographical potential of energy crops at three land-use categories. The highest geographical potential in the first half of the century is found in the Former USSR (region 11). East Asia (mainly China) is simulated to have the highest regional geographical potential in the second half of the century. Fig. 13 shows the regional availability of abandoned agricultural land for the eight most significant regions with the highest abandoned agricultural land area. These regions are identical in all scenarios; however, the variation in time differs by scenario. In the B1 and A1 scenario, the abandoned agricultural land area in East Asia (mainly China) increases rapidly at the end of the century. This is mainly caused by the decrease in population growth in this region at the end of the century. Simulations result in large surfaces of available area in Africa in the A1 and B1 scenarios. These are the scenarios with high levels of technological growth. As a result, food productivity is high. Subsequently, this results in a large share of abandoned agricultural land in these regions. In the $\mathrm{A} 1$ and $\mathrm{B} 1$ scenario, these regions are also assumed to increase their level of food import. This reduces the demand for agricultural land, so larger amounts of areas are assumed to become available for energy plantations in Africa.

The regional geographical potential of growing biomass (including all categories) in the 

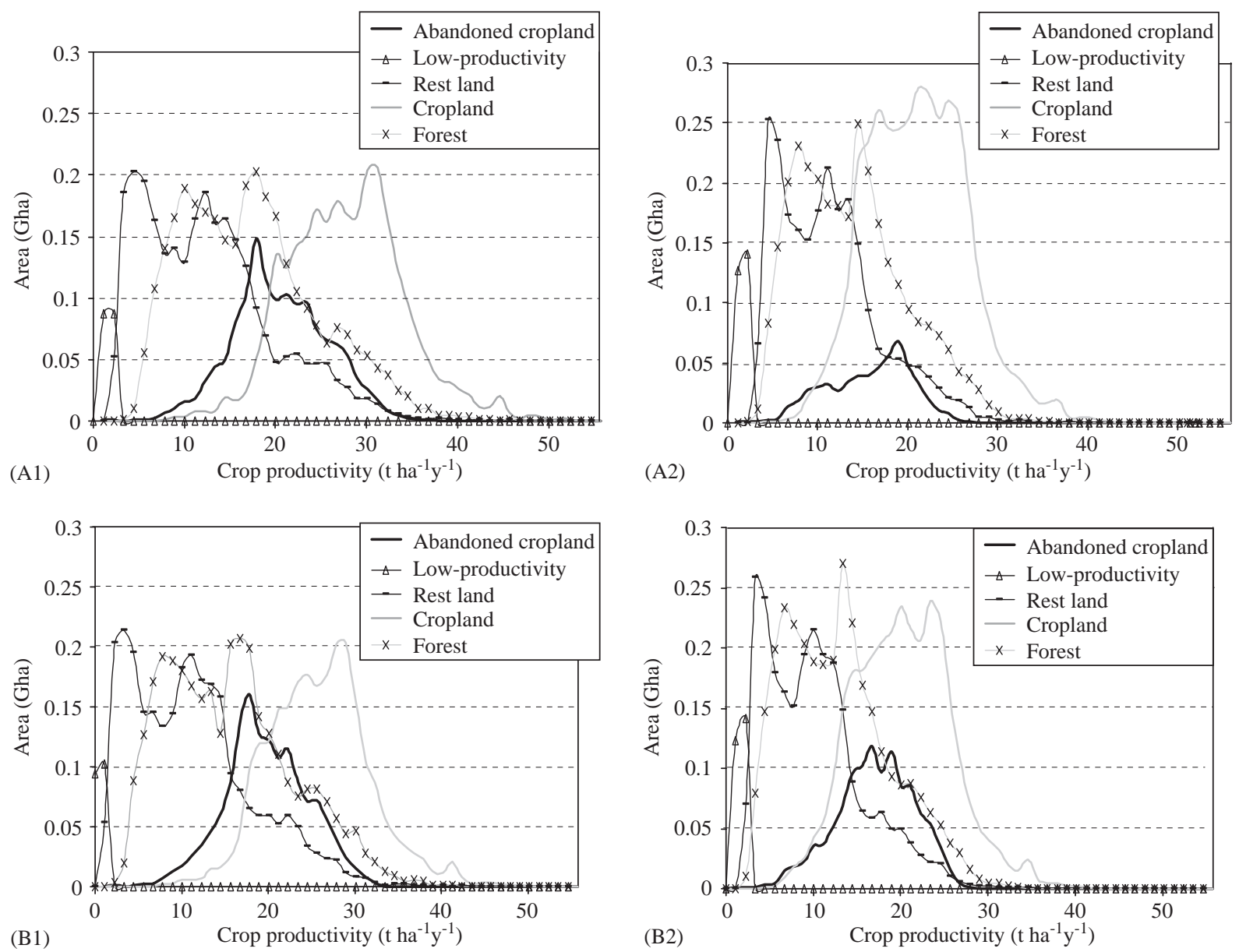

Fig. 10. Simulated productivity (including the management factor) of woody biomass energy crops in 2050 at the total global terrestrial surface, excluding the land-claim exclusion factor, for four SRES scenarios per land-use category distinguished in our study. It should be noted that for illustrative reasons we have plotted the land productivity in the selected cells as a functional relationship with the area, whereas this is not correct. A more correct representation would have been a histogram.

year 2050 exceeds the present primary energy demand in various regions. However, compared to the future regional energy demand simulated by IMAGE 2.2 this is not the case for all regions (Table 3). In none of the scenarios, the estimated global geographical potential in the year 2050 exceeds the projected total primary energy demand in that year. At a regional level, the geographical potential in Oceania and the Former USSR exceeds its regional energy demand in the year 2050 in all scenarios.

\section{The technical potential of biomass energy}

The technical potential of biomass energy is simply the product of the geographical potential and the conversion technology specific conversion efficiency $(\eta)$. The conversion efficiencies for the conversion to electricity are based on values presented in the literature; for biomass integrated gas combined cycle (BIG/CC) we used those of Dornburg and Faaij [60] and Faaij et al. [61]. For the transportation fuels we have based our estimates on $[32,34,62]$. Table 4 shows the 


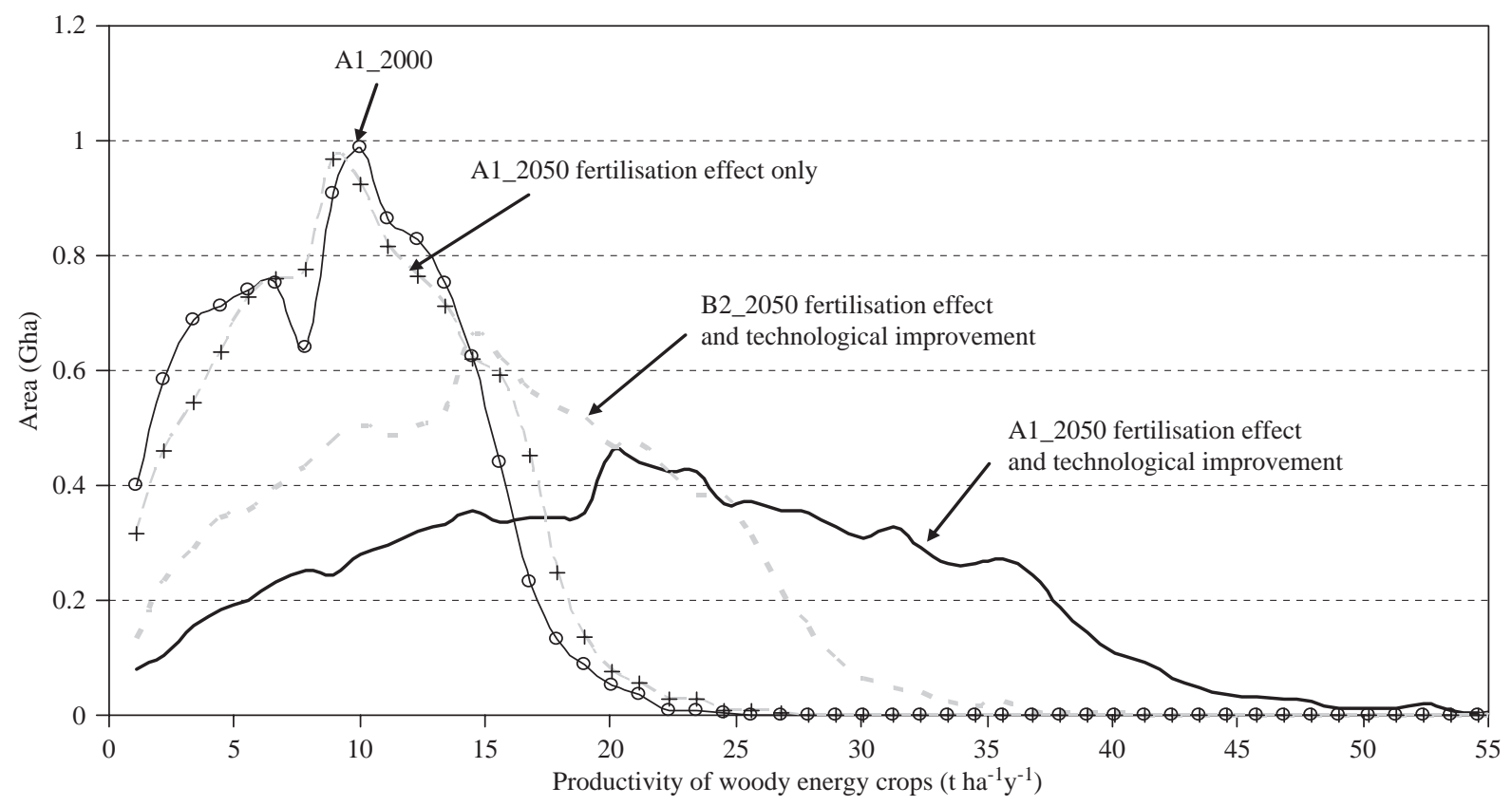

Fig. 11. Simulated productivity of woody biomass energy crops at the total global terrestrial surface for two SRES scenarios (A1 and B2). A curve is given for both the current (2000) and future (2050) situations, with and without technological improvements taking into account $\mathrm{CO}_{2}$ fertilisation effect.

efficiencies for the present and future situation of the technologies. For the future developments, ranges of exogenous technological improvements are assumed for the four SRES scenarios. The A1 and B1 scenarios are assumed to have large conversion plants that develop fast over time. The A2 and B2 scenarios are assumed to have a slower technological development, however reach the same upper level in 2050. The quantification of these assumptions is given in Table 4.

The technical potential is estimated for the year 2050 as presented in Table 5 for the two conversion technologies and the four scenarios.

\section{Sensitivity analysis and discussion}

The geographical potential of abandoned agricultural land is the highest of all categories. Furthermore, it is assumed to encounter less constraints regarding impact on vulnerable ecosystems and water resources, as these areas have previously been used for agricultural purposes. We therefore start with a sensitivity analysis on the availability of this land-use type at a regional level. We furthermore conduct a sensitivity analysis for the low-productive land and the rest land at a global level.

\subsection{Sensitivity of the available area from abandoned agricultural land}

The abandoned agricultural land estimated in this study varies widely for the four scenarios. The scenarios differ mainly according to:

- Population growth.

- GDP development.

- Technological development; i.e. the MF for food production.

- The degree of social/environmental prioritising; i.e. the diet.

- The degree of globalisation; i.e. the trade level. 
Table 2

Regional geographical potential of energy crops at three land-use categories for four scenarios, A1, A2, B1 and B2 for the year 2050 and 2100 (EJ yr ${ }^{-1}$ )

Energy crops: abandoned agricultural land
$\mathrm{A} 1$

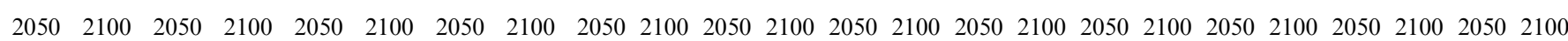

\begin{tabular}{lrrrrrrrrrrrrrrrrrrrrrrrrrrr}
\hline Canada & 14 & 17 & 9 & 10 & 13 & 12 & 12 & 15 & 2 & 1 & 3 & 2 & 2 & 2 & 3 & 2 & 4 & 3 & 3 & 2 & 1 & 0 & 1 & 0 \\
USA & 32 & 39 & 18 & 20 & 33 & 31 & 46 & 55 & 0 & 0 & 1 & 0 & 0 & 0 & 1 & 0 & 19 & 21 & 15 & 9 & 3 & 3 & 3 & 3 & 0 \\
Central America & 8 & 22 & 1 & 1 & 10 & 19 & 4 & 10 & 0 & 0 & 0 & 0 & 0 & 0 & 0 & 0 & 9 & 10 & 4 & 2 & 2 & 2 & 1 & 1 \\
South America & 53 & 73 & 1 & 1 & 56 & 70 & 37 & 41 & 1 & 0 & 1 & 0 & 1 & 0 & 1 & 1 & 32 & 33 & 24 & 12 & 6 & 5 & 6 & 5 \\
North Africa & 2 & 5 & 1 & 2 & 2 & 5 & 1 & 2 & 0 & 0 & 0 & 0 & 0 & 0 & 0 & 0 & 3 & 3 & 2 & 2 & 1 & 0 & 0 & 0 \\
West Africa & 20 & 69 & 3 & 36 & 22 & 58 & 2 & 25 & 0 & 0 & 0 & 0 & 0 & 0 & 0 & 0 & 29 & 27 & 20 & 16 & 5 & 4 & 4 & 3 \\
East Africa & 15 & 49 & 1 & 13 & 17 & 41 & 2 & 5 & 0 & 0 & 0 & 0 & 0 & 0 & 0 & 0 & 24 & 25 & 14 & 12 & 4 & 4 & 3 & 2 \\
South Africa & 24 & 83 & 1 & 36 & 26 & 66 & 1 & 35 & 0 & 0 & 0 & 0 & 0 & 0 & 0 & 0 & 17 & 18 & 9 & 8 & 4 & 3 & 2 & 2 \\
Western Europe & 9 & 16 & 10 & 11 & 9 & 14 & 15 & 17 & 0 & 0 & 0 & 0 & 0 & 0 & 0 & 0 & 4 & 5 & 4 & 4 & 1 & 1 & 1 & 1 \\
East Europe & 9 & 12 & 8 & 10 & 8 & 10 & 9 & 11 & 0 & 0 & 0 & 0 & 0 & 0 & 0 & 0 & 0 & 0 & 0 & 0 & 0 & 0 & 0 & 0 \\
Former USSR & 97 & 147 & 47 & 63 & 83 & 101 & 74 & 106 & 1 & 0 & 3 & 1 & 2 & 1 & 2 & 1 & 27 & 33 & 21 & 25 & 5 & 4 & 4 & 5 \\
Middle East & 2 & 13 & 1 & 2 & 2 & 10 & 1 & 2 & 0 & 0 & 0 & 0 & 0 & 0 & 0 & 0 & 11 & 11 & 7 & 7 & 2 & 2 & 2 & 1 \\
South Asia & 12 & 49 & 3 & 8 & 11 & 38 & 4 & 15 & 0 & 0 & 0 & 0 & 0 & 0 & 0 & 0 & 13 & 14 & 11 & 10 & 3 & 2 & 1 & 1 \\
East Asia & 79 & 181 & 7 & 11 & 74 & 127 & 43 & 61 & 1 & 1 & 1 & 1 & 1 & 1 & 1 & 1 & 22 & 35 & 16 & 23 & 4 & 4 & 3 & 4 \\
South East Asia & 1 & 28 & 1 & 1 & 1 & 19 & 2 & 10 & 0 & 0 & 0 & 0 & 0 & 0 & 0 & 0 & 8 & 6 & 6 & 2 & 2 & 1 & 1 & 1 \\
Oceania & 32 & 42 & 17 & 17 & 31 & 34 & 26 & 36 & 0 & 0 & 0 & 0 & 0 & 0 & 0 & 0 & 21 & 22 & 17 & 14 & 4 & 4 & 3 & 3 \\
Japan & 0 & 2 & 0 & 1 & 0 & 1 & 0 & 2 & 0 & 0 & 0 & 0 & 0 & 0 & 0 & 0 & 0 & 0 & 0 & 0 & 0 & 0 & 0 & 0 \\
World & 409 & 847 & 129 & 243 & 398 & 656 & 279 & 448 & 5 & 2 & 9 & 4 & 6 & 4 & 8 & 5 & 243 & 266 & 173 & 148 & 47 & 39 & 35 & 32 \\
\hline
\end{tabular}




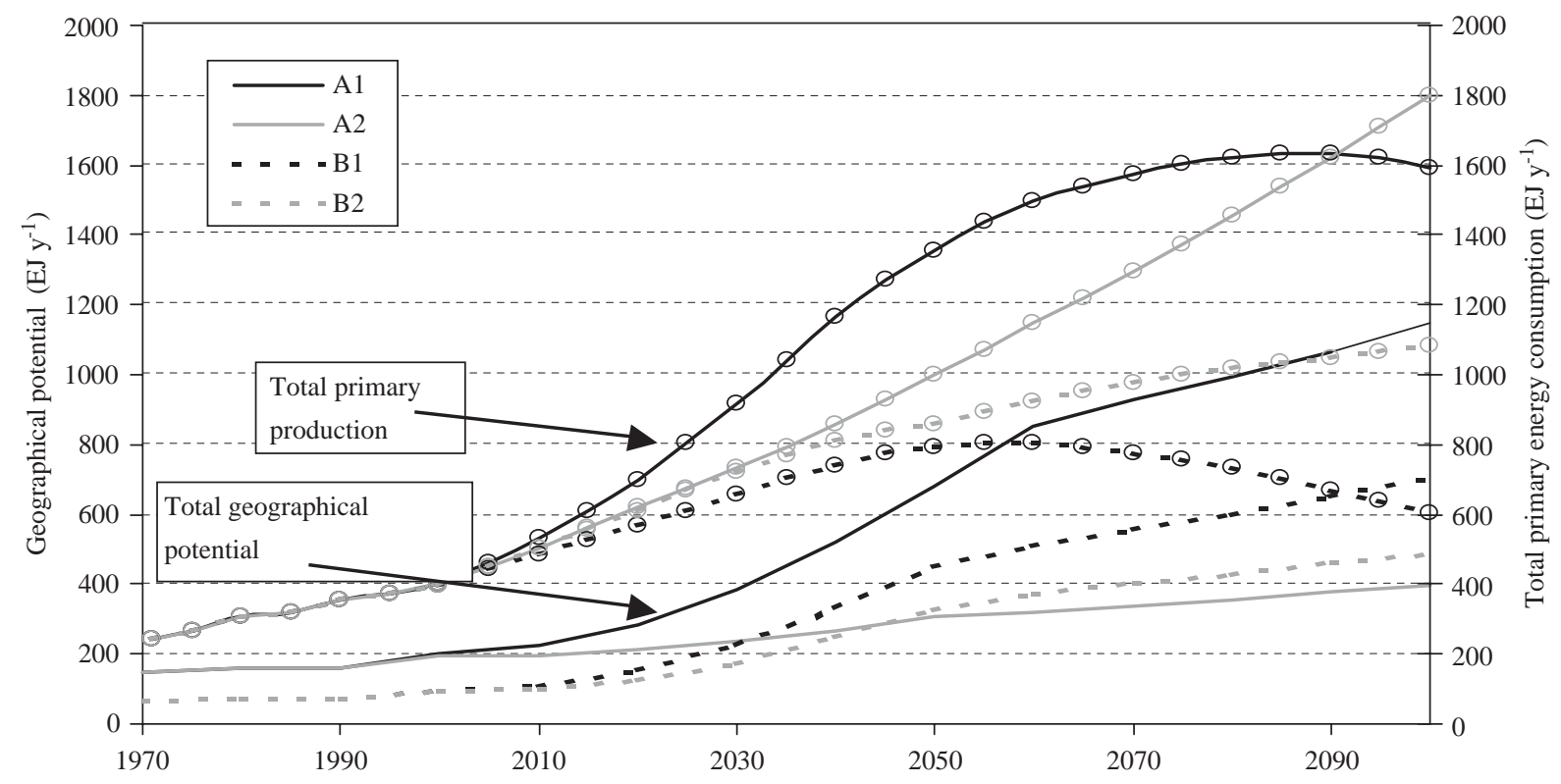

Fig. 12. Geographical potential of woody biomass energy crops as assessed for the four SRES scenarios over time, as well as the simulated total primary energy consumption. The latter is differentiated from the graphs of the geographical potential by circles in the graphs.

In the IMAGE 2.2 model, the following relations of these factors with the geographical potential are included:

- The population growth influences the demand for food or fodder crops.

- The GDP influences the type of crop that is used for fodder. If a large amount of capital is available, the animals are fed with high-quality food crops, whereas otherwise large shares of food residues are used. Furthermore, the GDP is included in the assessment of the ratio between affluent and basic types of food. An increase of GDP increases the share of affluent food intake (e.g. animal intake and oil crops).

- The technical development of the production of food or fodder is determined by the MF.

- If a world is more or less environmentally oriented, this is reflected in the amount of meat that is consumed in the diet; e.g. in the B1 scenario, the meat consumption declines.

- The globalisation or regionalisation is reflected in the level of trade that is assumed in the scenario. The B1 and A1 scenarios have maximum trade, so the desired food demand can be imported from other regions; or regions extend their food production to higher levels, so it can be exported to other regions.

To analyse the effect of these factors on the geographical potential of biomass energy, we have taken the parameterisation of the B1 scenario and converted it to the A2 scenario by varying one factor each run. The B1 and A2 scenarios represent the outer boundaries of the food demand and the required agricultural land area and are therefore interesting to use for these analyses. The variations over time for the amount of required agricultural land area are shown in Fig. 14. From Fig. 14, it can be seen that:

- The global agricultural land area in the B1 scenario reduces over time, from about 3.1 Gha in 2000 to $1.6 \mathrm{Gha}$ in 2100 . Whereas the agricultural land area in the A2 scenario slightly increases, from $3.1 \mathrm{Gha}$ in 2000 to about 4.2 Gha in 2100 . 

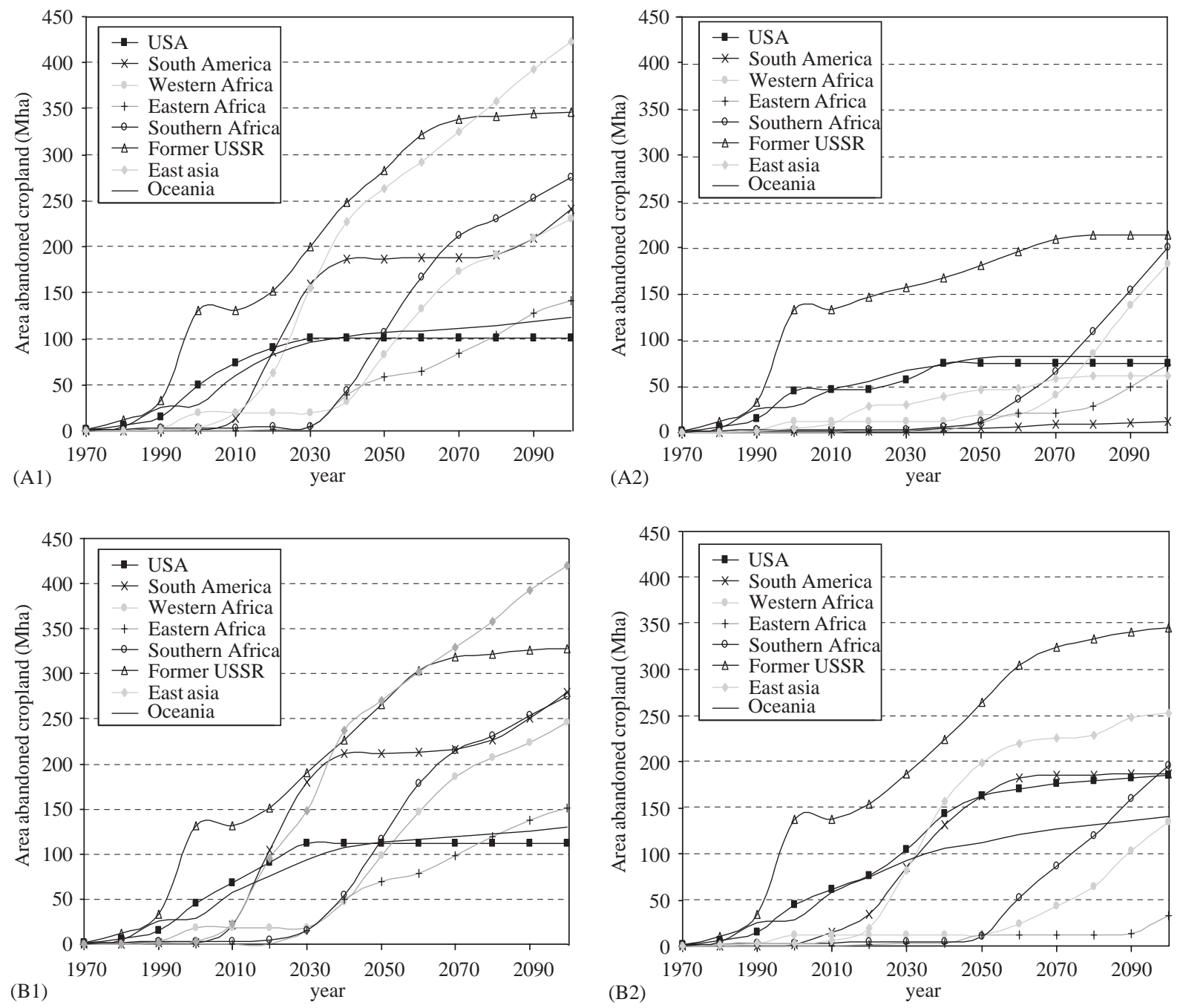

Fig. 13. Regional variation over time of abandoned agricultural land area (Mha) as simulated by IMAGE 2.2 for four SRES scenarios. Only regions with high amounts of abandoned land are included.

- The agricultural land area of the B1 scenario increases by $250 \%$ to 4 Gha in 2100 if we use the population figures from the A2 scenario.

- The agricultural land area reduces slightly (still about 240\% higher than B1) if the lower GDP values of the A2 scenario are used. A higher GDP increases the quality of the fodder and so improves the feed efficiency of the animal, however, more food crops are required. The agricultural land area is reduced because the food crops demand is less in the A2 scenario and the affluent food demand is reduced.
- The effect of the lower MF for the food production influences the agricultural land area only in the beginning of the century, as the technological change is assumed to be saturated at the end of the century. The agricultural land area at the end of the century is similar to the situation using the MF from the B1 scenario.

- When using the consumed diet from the A2 scenario, the agricultural land area increases to about $290 \%$ compared to B1. In the B1 scenario, the meat consumption is low, whereas it is high in the A2 scenario. This is reflected in 
the agricultural area required for the food and fodder crops.

- In the final run, we also used the food trade balance of the A2 scenario. If trade is used in an optimal way, high trade levels are expected to reduce the agricultural land area. However, as can be seen from Fig. 14, the lower trade levels of the A2 scenario decrease the agricultural land area. This was not expected, but is caused by the exogenous setting of the trade balance in the IMAGE 2.2 model, which is mainly based on an extrapolation of the historical trend. Fig. 14 shows that the final run is close to the A2

Table 3

Ratio of the regional geographical potential of growing biomass in 2050 compared to the projected primary energy consumption in the year 2050, taken from [19]

\begin{tabular}{lcccc}
\hline & A1 & A2 & B1 & B2 \\
\hline Canada & 1.1 & 0.8 & 1.4 & 1.2 \\
USA & 0.4 & 0.2 & 0.4 & 0.5 \\
Central America & 0.4 & 0.1 & 0.3 & 0.2 \\
South America & 0.9 & 0.3 & 1.0 & 0.7 \\
North Africa & 0.1 & 0.1 & 0.1 & 0.1 \\
West Africa & 1.3 & 1.1 & 1.0 & 0.3 \\
East Africa & 1.7 & 1.4 & 1.3 & 0.4 \\
South Africa & 1.1 & 0.4 & 1.1 & 0.1 \\
OECD Europe & 0.1 & 0.2 & 0.1 & 0.2 \\
East Europe & 0.3 & 0.3 & 0.5 & 0.4 \\
Former USSR & 1.4 & 1.1 & 1.9 & 1.4 \\
Middle East & 0.1 & 0.1 & 0.1 & 0.0 \\
South Asia & 0.1 & 0.1 & 0.1 & 0.0 \\
East Asia & 0.5 & 0.2 & 0.7 & 0.3 \\
South East Asia & 0.1 & 0.2 & 0.1 & 0.1 \\
Oceania & 6.0 & 4.0 & 6.1 & 4.4 \\
Japan & 0.0 & 0.0 & 0.0 & 0.0 \\
World & 0.5 & 0.3 & 0.6 & 0.4 \\
\hline
\end{tabular}

scenario, so other parameters, e.g. cropping intensity, are not of high importance for the results.

The A2 scenario still includes the assumption of significant crop management improvements over time (see Fig. 4). If there would be no technological improvements at all, the agricultural land area would rise to 5.7-6.5 Gha in, respectively, 2050 and 2100 (see Fig. 14), compared to 3.7 and 4.2 Gha in 2050 and 2100 with the default MF. This is seen as the upper boundary of the agricultural land area requirement. This would enhance the pressure on the land-use system significantly and would lead to marginal energy crop potentials, as the abandoned agricultural land for this situation is simulated to be 0.44 (2050)-0.71 Gha (2100).

In Table 6, the results are shown of the sensitivity analysis on the geographical potential for abandoned agricultural land in the year 2050 . We have also included the sensitivity to the productivity of the energy crop by varying the MF of energy crops in the B1 scenario $( \pm 25 \%)$. It can be seen that the population and the MF of the food crops are of high importance for the geographical potential. Especially like South America and the African region the MF of food crops, i.e. the technological development of the agriculture is of high importance for the geographical potential of energy crops. This is less important in more developed regions as Canada, Oceania, Europe and the Asian region. These encounter significant impacts from variation in the population figures. In OECD Europe, the

Table 4

Summary of the parameters required for the two conversion technologies

\begin{tabular}{lll}
\hline & Electricity & Transport fuel \\
\hline Conversion route/type of fuel & Gasification-combined cycle & Gasification/hydrolysis fermentation \\
Typical scale (MWth) & $20-1000$ & $100-2000$ \\
Status & Demonstration & Laboratory $/$ demonstration \\
Conversion efficiency $(\%)$ (year 2000) & 40 & 40 \\
Conversion efficiency (\%) (year 2050) & 56 & 55
\end{tabular}

\footnotetext{
${ }^{\text {a }}$ Fischer-Tropsch using biomass is in the pilot scale; however, the conversion of coal to Fischer-Tropsch oil is commercial already. Several companies have or are developing positions in Fischer-Tropsch technology, Sasol, BP, ExxonMobile, ENI and Shell.
} 
Table 5

Technical potential of biomass energy for the year 2050 for four SRES scenarios compared to the present consumption [59,67]

\begin{tabular}{|c|c|c|c|c|c|c|c|c|c|}
\hline & \multicolumn{2}{|l|}{ A1 } & \multicolumn{2}{|l|}{ A2 } & \multicolumn{2}{|l|}{ B1 } & \multicolumn{2}{|l|}{$\mathrm{B} 2$} & \multirow{2}{*}{$\begin{array}{l}\text { Present }(2000) \text { global } \\
\text { consumption }\end{array}$} \\
\hline & 2050 & 2100 & 2050 & 2100 & 2050 & 2100 & 2050 & 2100 & \\
\hline Geographical potential $\left(\mathrm{EJ} \mathrm{yr}^{-1}\right)$ & 657 & 1115 & 311 & 395 & 451 & 699 & 322 & 485 & \\
\hline Electricity $\left(\mathrm{PWh} \mathrm{yr}^{-1}\right)$ & 132 & 225 & 63 & 80 & 91 & 141 & 65 & 98 & $15 \mathrm{PWh} \mathrm{yr}^{-1}$ \\
\hline Fuel $\left(\mathrm{EJ} \mathrm{yr}^{-1}\right)$ & 361 & 613 & 171 & 217 & 248 & 384 & 177 & 267 & $142 \mathrm{EJ} \mathrm{yr}^{-1 \mathrm{a}}$ \\
\hline
\end{tabular}

${ }^{\mathrm{a}}$ This is the oil consumption for the year 1998.

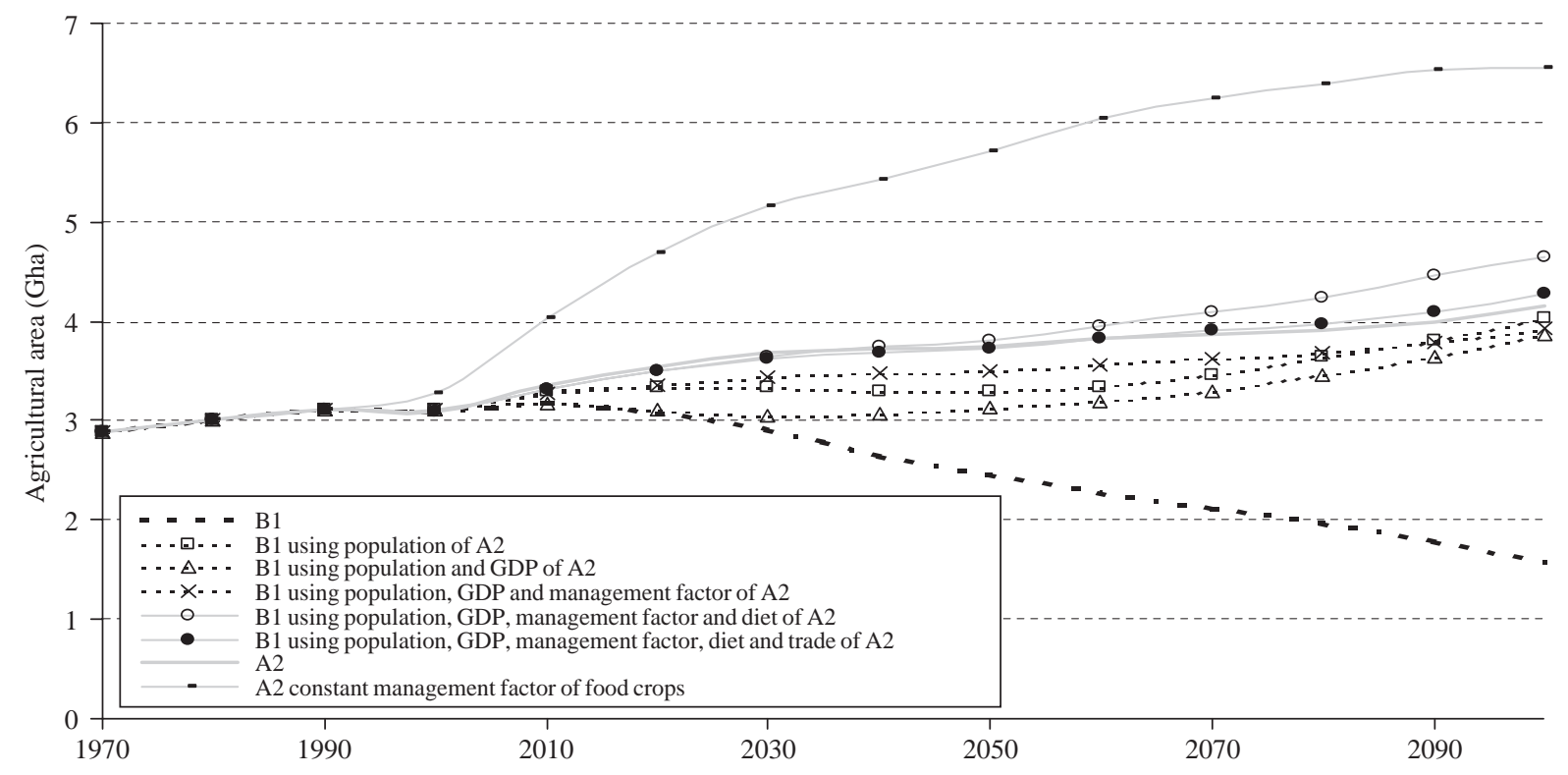

Fig. 14. Global agricultural land area over time for several scenarios that convert the B1 scenario to A2 in various steps, as simulated by the IMAGE 2.2 model.

potential is even higher in the A2 scenario in the year 2050, because of the high trade levels assumed in the B1 scenario. The global results for all categories are shown in Table 7.

The sensitivity analysis of the technical potential is straightforward as the technical potential is linearly dependent on the geographical potential via the conversion efficiency. For instance, a variation in the geographical potential from 342 to $618 \mathrm{EJ} \mathrm{yr}^{-1}$ (i.e. total geographical potential of B1 scenario for low MF and high MF), the technical potential for electricity ranges from 56 to $101 \mathrm{PWh} \mathrm{yr}^{-1}$.
7.2. Comparison of the geographical potential with previous studies

Various studies have analysed the global potential of biomass energy. Berndes et al. [8] have made an extensive overview of many of these studies. Found in the previous studies was that, for the first half of the century, energy crop potentials are estimated ranging from 14 [26] to $267 \mathrm{EJ} \mathrm{yr}^{-1}$ [27]. To understand the differences between the outcomes, we compare the results found for 2050 in this study with previous studies on the energy crop productivity and the available area (Fig. 15). 
Table 6

Sensitivity of the geographical potential of abandoned agricultural land (in $\mathrm{EJ} \mathrm{yr}^{-1}$ ) for the year 2050 to various input parameters, the management factor (MF) of the energy crop and to scenario parameters, the population, GDP, food crop management factor, diet, trade and exclusion factor

\begin{tabular}{|c|c|c|c|c|c|c|c|c|c|c|}
\hline & $\begin{array}{l}\text { B1 low } \\
\text { MF }\end{array}$ & $\begin{array}{l}\text { B1 high } \\
\text { MF }\end{array}$ & $\mathrm{B} 1$ & $\begin{array}{l}\text { B1 using } \\
\text { population } \\
\text { A2 }\end{array}$ & $\begin{array}{l}\text { B1 using } \\
\text { population } \\
\text { and GDP } \\
\text { A2 }\end{array}$ & $\begin{array}{l}\text { B1 using } \\
\text { population, } \\
\text { GDP and } \\
\text { MF A2 }\end{array}$ & $\begin{array}{l}\text { B1 using } \\
\text { population, } \\
\text { GDP, MF } \\
\text { and diet A2 }\end{array}$ & $\begin{array}{l}\text { B1 using } \\
\text { population, } \\
\text { GDP, MF, } \\
\text { diet and } \\
\text { trade A2 }\end{array}$ & $\begin{array}{l}\text { B1 using } \\
\text { population, } \\
\text { GDP, MF, } \\
\text { diet, trade } \\
\text { and } \\
\text { exclusion } \\
\text { factor A2 }\end{array}$ & A2 \\
\hline Canada & 10 & 16 & 13 & 12 & 12 & 9 & 8 & 9 & 9 & 9 \\
\hline USA & 25 & 41 & 33 & 27 & 27 & 16 & 12 & 17 & 18 & 18 \\
\hline Central America & 7 & 12 & 10 & 1 & 1 & 0 & 0 & 1 & 1 & 1 \\
\hline South America & 42 & 71 & 56 & 26 & 26 & 0 & 0 & 0 & 0 & 1 \\
\hline Northern Africa & 1 & 2 & 2 & 1 & 1 & 1 & 1 & 1 & 1 & 1 \\
\hline Western Africa & 17 & 28 & 22 & 16 & 16 & 5 & 6 & 3 & 3 & 3 \\
\hline Eastern Africa & 13 & 22 & 17 & 11 & 11 & 6 & 4 & 1 & 1 & 1 \\
\hline Southern Africa & 19 & 32 & 26 & 17 & 17 & 2 & 1 & 2 & 2 & 1 \\
\hline OECD Europe & 6 & 11 & 9 & 8 & 8 & 6 & 6 & 9 & 10 & 10 \\
\hline Eastern Europe & 6 & 10 & 8 & 7 & 7 & 5 & 4 & 7 & 7 & 8 \\
\hline Former USSR & 62 & 103 & 83 & 64 & 64 & 39 & 37 & 45 & 46 & 47 \\
\hline Middle East & 1 & 2 & 2 & 2 & 2 & 1 & 1 & 1 & 1 & 1 \\
\hline South Asia & 8 & 14 & 11 & 6 & 6 & 6 & 5 & 2 & 3 & 3 \\
\hline East Asia & 55 & 92 & 74 & 27 & 27 & 29 & 20 & 11 & 11 & 7 \\
\hline South East Asia & 1 & 2 & 1 & 1 & 1 & 1 & 1 & 1 & 1 & 1 \\
\hline Oceania & 23 & 38 & 31 & 26 & 26 & 19 & 15 & 16 & 16 & 17 \\
\hline Japan & 0 & 1 & 0 & 0 & 0 & 0 & 0 & 0 & 0 & 0 \\
\hline World & 298 & 496 & 397 & 253 & 253 & 148 & 123 & 127 & 131 & 129 \\
\hline
\end{tabular}




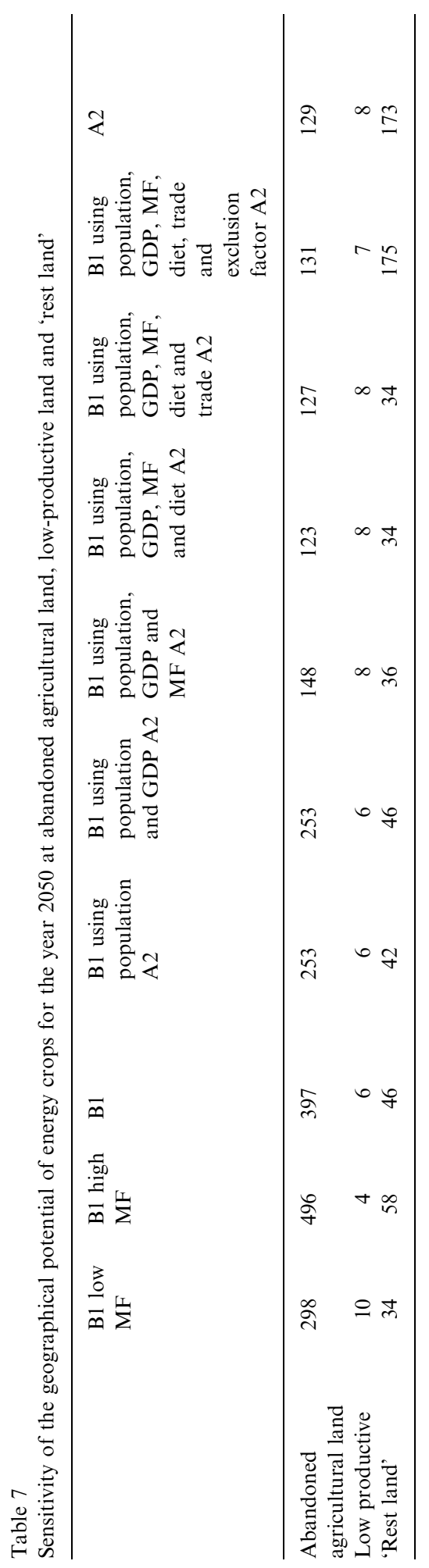

We only compare the area assumed to be available from abandoned agricultural land, as this dominates the geographical potential in previous studies as well as in ours.

From Fig. 15 it can be seen that, except for the study conducted at IIASA [12], the estimated available area in this study is high compared to previous studies for the A1 and B1 scenarios. These scenarios simulate an optimistic situation for abandoned agricultural land, as the population growth slows down over time. Also there is an important role for technological improvement expected in these scenarios. Less optimistic scenarios, like B2 or A2 have outcomes in the same order as previous studies. Most studies have restricted the available land to abandoned agricultural land because of surplus or degraded cropland for energy crop production. For instance, Hall et al. [27] and Swisher and Wilson [63] assume that energy crops can be planted at only $10 \%$ of the abandoned agricultural land area in industrialised regions and at all degraded areas. This results in an available area of around $0.4-1$ Gha for the year 2025-2030. This is comparable to our abandoned agricultural land category, ranging from 0.5 (A2) to $1.4 \mathrm{Gha}$ (A1). The difference is, however, that most of the available land in our study is found in developing regions, whereas Hall et al. [27] assume abandoned agricultural land to become available in industrialised regions. Fischer and Schrattenholzer [12] use a different assumption regarding the available land for energy crops, as they assume energy crop production at grassland only. If we apply this restriction to our figures (using the crop productivity at grassland/steppe), the geographical potential would be reduced to $195-200 \mathrm{EJ} \mathrm{yr}^{-1}$. This is the same order of magnitude as the geographical potential mentioned by Fischer and Schrattenholzer [12] of 154-205 $\mathrm{EJ} \mathrm{yr}^{-1}$ for energy crops in the year 2050. Both studies have estimated the energy crop productivity at grid cell level, this seems to give similar results. Other studies assume fixed productivity levels at a global scale $[10,27,63]$. These productivities are lower than the (average) productivities computed in this study. The MF for energy crops assumed in this study seems high compared to assumptions in other studies. This is the case for all scenarios. 


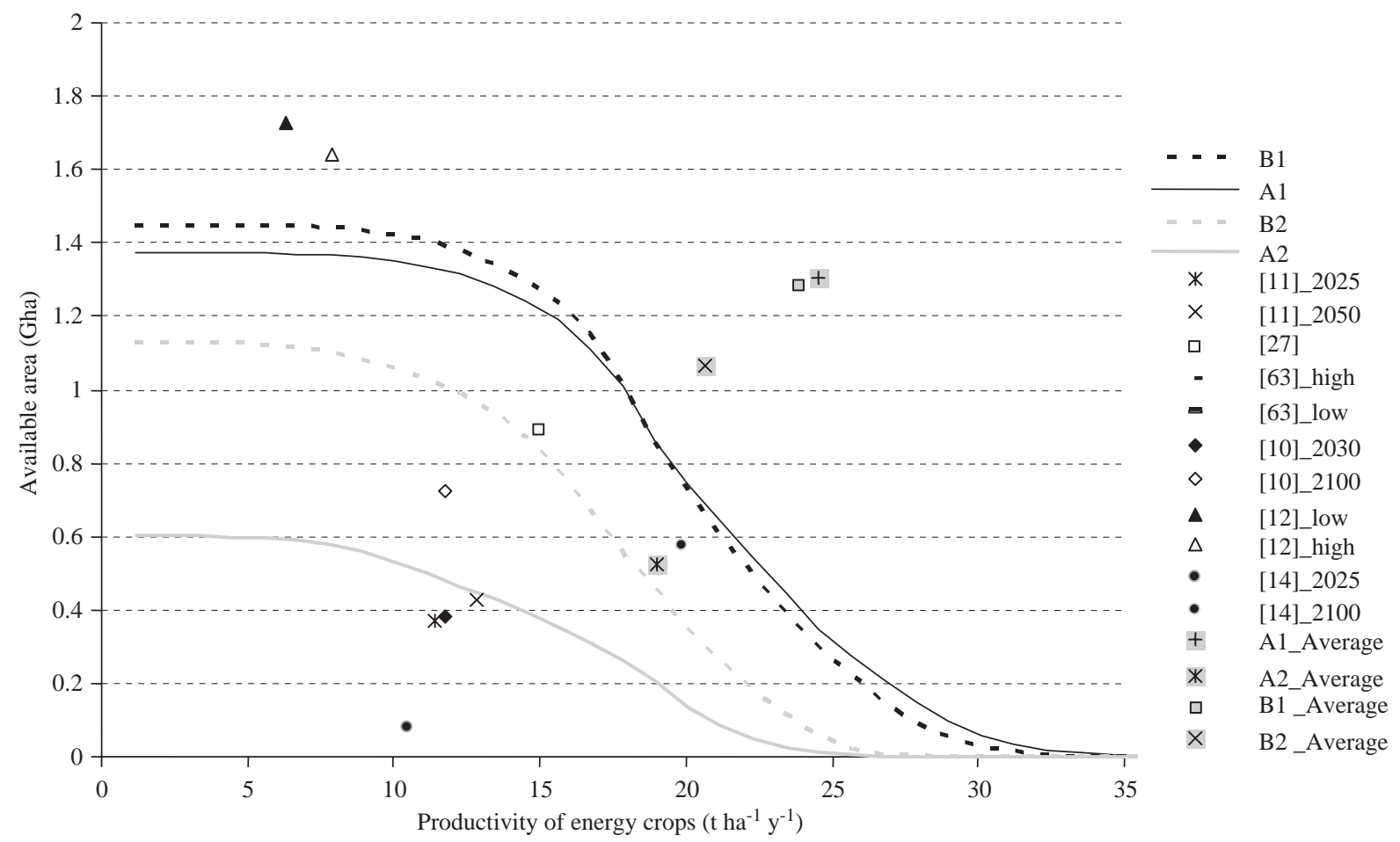

Fig. 15. Estimated available abandoned agricultural land area (in the year 2050 for this study) and the corresponding average yields as simulated in this study and by previous biomass energy potential studies, for [14], land availability has been derived from their graphs and also given in [8]. Note that not all studies have bee conducted for the year 2050, but range from 2025 to 2100.

Most studies have not incorporated significant productivity improvements over time. However, when comparing the improvements encountered for food crops, we consider these improvements to be attainable for energy crops too, although more research is required. Based on the comparison with the other studies we conclude that the results of $\mathrm{A} 1$ and $\mathrm{B} 1$ scenarios found in this study are high compared to other studies, mainly due to high amounts of available land and high productivity levels as the result of the assumed population reduction over time and high level of technological learning which increases the productivity rapidly. The B2 and A2 scenarios that are assumed to have higher population growth and less rapid technological learning result in geographical potentials that are in the same order of the figures found in the literature.

\subsection{Discussion of results}

Before discussing the results in detail, we stress that although the assessment of the geographical potential of energy crops has been conducted at grid cell level, the results are aggregated to a regional level and it is this level that needs to be considered as the level at which the results are applicable to.

To what extent the regional geographical or technical potential of biomass energy can become available depends on various factors outside the scope of this study, like the import and export of biomass energy and on the willingness to invest in energy plantations. Furthermore, it depends on factors that are included in this study and are weakly understood, e.g. the land-claim exclusion factor for 'rest land'. Finally, it depends on factors that are not taken into account in this study due to 
limitations of the approach, e.g. the change in the pressure on the land-use system. The pressure on the land quality (e.g. the depletion of the water and nutrient resources) is not included in this study at grid cell level. This pressure can be significant if energy crops are implemented at large scale. As woody energy crops have deeper roots, their pressure on groundwater availability is higher than for food crops. Based on a scenario study regarding the introduction of about $304 \mathrm{EJ} \mathrm{yr}^{-1}$ of biomass energy in the energy system, Berndes [64] concludes that large-scale energy crop implementation would in some countries lead to a further enhancement of already stressed water situation (e.g. South Africa, Poland). In countries that currently do not experience water stress, a largescale expansion of biomass energy could induce a more difficult situation (e.g. India, China). But there are also countries where such impacts are less likely to occur (e.g. USA, Canada, Brazil, Russia). Although Berndes' analysis is benign for the regions that have large geographical potential levels simulated in this study, it is highly recommended to include the water availability in a future analysis, preferable at regional level, especially when assuming land available at rest land types, e.g. savannah. Similar applies to nutrient availability in the soil, although this type of soil degradation depends highly on the management of the energy plantation, the amount and type of fertilisers applied and the use of the branches and leaves of the crop (e.g. [28]). These limitations need to be taken into account when using the outcomes of this study, as the ranges of the geographical potential of energy crops may be broader than indicated here. In this context, it is also noted that above-mentioned aspects may also be different for non-woody, e.g. herbaceous energy crops. This is therefore an additional reason to study these crops in future work.

In this study, we have corrected competing landuse claims with care. However, as mentioned before, the choice of the land-claim exclusion factor for 'rest land' area is rather arbitrary. The chosen value does have a significant impact on the geographical potential. Because the value for the future depends mainly on local factors and cannot be measured, no generic value over the world or at regional level can be estimated. The results of the geographical potential of 'rest land' area should therefore be considered with care.

Finally, it should be noted that using the total of the potential covering three types of land-use categories is extreme and theoretical, as it would imply an area of almost $30-40 \%$ of the total land area. These values are in the same order of magnitude up to $200 \%$ of the current agricultural land area.

\section{Summary and conclusion}

In this study, we have estimated the geographical and technical potential of produced biomass for energy purposes (energy crops) at grid cell level for the four IPCC SRES scenarios: A1, A2, B1 and B2, using the IMAGE 2.2 model. These scenarios vary according to the population and economic growth, the technological change, social behaviour, the value that is given to environmental and ecological issues and the level of globalisation. The geographical potential is the product of the available area for energy crops and the productivity level. Three categories of potential available areas are distinguished: (1) abandoned agricultural land; (2) low-productive land; and (3) rest land not required for food, forest or bioreserves. The potential of low-productive land is negligible. The global geographical potential of the three land-use categories for the year 2050 and 2100 for the four scenarios is summarised in Table 8 .

The geographical potential of abandoned agricultural land is found to be the largest for the A1 and B1 scenario. For these scenarios, the potentials are comparable to the present energy consumption of about $400 \mathrm{EJ} \mathrm{yr}^{-1}$ [59]. The ratio between the total geographical potential and the future energy demand is in most regions below 1, which means that the regional potential does not exceed the regional projected primary energy demand. Oceania does have the largest relative geographical potential; e.g. the geographical potential in the year 2050 does exceed the energy demand in the year 2050 for all scenarios. For the B1 scenario, this ratio is about 6 . In absolute terms, the Former USSR has the highest potential, 
Table 8

Global geographical potential for the years 2050 and 2100 for three land-use categories for the four scenarios $\left(\mathrm{EJ} \mathrm{yr}^{-1}\right)$

\begin{tabular}{|c|c|c|c|c|c|c|c|c|}
\hline & \multicolumn{2}{|l|}{ Al } & \multicolumn{2}{|l|}{ A2 } & \multicolumn{2}{|l|}{$\mathrm{B} 1$} & \multicolumn{2}{|l|}{$\mathrm{B} 2$} \\
\hline & 2050 & 2100 & 2050 & 2100 & 2050 & 2100 & 2050 & 2100 \\
\hline \multicolumn{9}{|l|}{ At abandoned agricultural land } \\
\hline Primary biomass & 409 & 847 & 129 & 243 & 398 & 656 & 279 & 448 \\
\hline Biomass fuel & 225 & 466 & 71 & 134 & 219 & 361 & 153 & 246 \\
\hline Biomass electricity $\left(\mathrm{PWh} \mathrm{yr}^{-1}\right)$ & 82 & 171 & 26 & 49 & 80 & 132 & 56 & 90 \\
\hline \multicolumn{9}{|l|}{ At low-productive land } \\
\hline Primary biomass & 5 & 2 & 9 & 4 & 6 & 4 & 8 & 5 \\
\hline Biomass fuel & 3 & 1 & 5 & 2 & 3 & 2 & 4 & 3 \\
\hline Biomass electricity $\left(\mathrm{PWh} \mathrm{yr}^{-1}\right)$ & 1 & 0 & 2 & 1 & 1 & 1 & 2 & 1 \\
\hline \multicolumn{9}{|l|}{ At rest land } \\
\hline Primary biomass & 243 & 266 & 173 & 148 & 47 & 39 & 35 & 32 \\
\hline Biomass fuel & 134 & 146 & 95 & 81 & 26 & 21 & 19 & 18 \\
\hline Biomass electricity $\left(\mathrm{PWh} \mathrm{yr}^{-1}\right)$ & 49 & 54 & 35 & 30 & 9 & 8 & 7 & 6 \\
\hline
\end{tabular}

reaching levels in 2050 of about 71 (A2)-125 (A1)

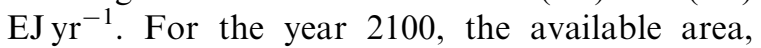
and so the geographical potential of abandoned agricultural land, is about doubled; at 'rest land', it remains almost constant.

The results are most significant for the $\mathrm{A} 1$ and B1 scenarios. Both scenarios describe a world with decreasing population growth in the second half of the century and a world in which the technical development is high. The food productivity levels are high because of high management levels and high crop intensities. In the B1 scenario, the world is highly oriented towards environmental, ecological and social values. Therefore, competing landuse options, like nature conservation, are higher than in the A1 scenario. However, there is still a high potential left in this scenario. The A2 scenario has the lowest geographical potential. It is a world with rapid population growth up to 15 billion people in the year 2100. It furthermore experiences less technical development, is region oriented and is market-based growth oriented towards economic development. As food trade is not assumed, the food supply needs to be produced within the region. In this world, the pressure on the land-use system is already high. In North Africa and the Middle East, people have to adapt their food intake to lower levels, as the expected (high) demand cannot be satisfied within the region.
Furthermore, large areas ( $\sim 700 \mathrm{Mha})$ are deforested in this scenario for the establishment of agricultural land. As in scenario A2 the ecological values are not considered important, reforestation is not expected. However, if these areas would be reforested, the potential of biomass at abandoned agricultural land would decrease even further with about $140 \mathrm{EJ} \mathrm{yr}^{-1}$, assuming an average energy crop productivity of $13 \mathrm{tha}^{-1} \mathrm{yr}^{-1}$. Due to climate change, which is severe in this scenario, the landuse pattern changes and land is taken out of production not because of surplus agricultural land, but because of a shift towards more suitable areas. The remaining land is estimated in this study as abandoned agricultural land. Nevertheless, if the total geographical potential of biomass energy is produced in this scenario, the stress on the land-use system will even increase.

Except for the scenario driving forces, we have so far not included economic, social or political factors. These might be important. For instance, large available areas are found in the African regions in the $\mathrm{A} 1$ and $\mathrm{B} 1$ scenarios, i.e. scenarios with significant technological growth. The sensitivity analysis shows that the assumption of the MF for food crops is of high importance for this value of geographical potential in these regions. Significant technological and organisational improvements in the agricultural sector in these 
regions are required to reach this potential. This is only possible if the issue of food security and improvement of food production system increases on the international agenda and if the political situation in Africa improves the coming decades.

This study gives insight in the geographical potential of biomass energy using different landdynamic scenarios. Interesting conclusions have been drawn in this study. However, also some more aspects are acknowledged that give rise to recommendations for further research:

- This study has focused on biomass from energy crops only. The inclusion of biomass from residues using the IPCC scenarios requires a dynamic model that includes the demand and supply of forestry products in an integrated and detailed manner including the effect of cascading.

- We have only included the impact of land degradation by means of climatic change, e.g. increase of temperature and rainfall. However, if land resources are used in an intensive way that reduces the organic content of the soil, the productivity is significantly reduced. This feedback is not incorporated in this analysis. Inclusion of this mechanism can reduce the land productivity and consequently the geographical potential.

- Related to the land degradation due to bad management, inclusion of more variation in the energy crop and food crop production systems is needed. One may think of varying the rotation length, the harvest index or the amount of nutrient applied. These different production systems result also in different yields of the food and energy crops and consequently in different geographical potentials.

- It is recommended to study the geographical potential of rest land in more detail. This study has shown that significant amounts of biomass can be produced at these areas. However, the reduction of the available land by means of impact on vulnerable ecosystems or water resources, etc. is conceptually difficult to quantify and could only be roughly estimated in this study. Further research that for instance includes the required land for remaining the biodiversity or water security can be combined with studies on the available rest land area to get a more underpinned estimated of the landclaim exclusion factor.

\section{Acknowledgements}

We are grateful to Pita Verweij of the Utrecht University, Lee Lynd of the Thayer School of Engineering Dartmouth College and Bart Strengers of the RIVM for their comments on earlier drafts and to Lex Bouwman of the RIVM for his support with the exclusion factor for the grazing systems.

\section{References}

[1] RWEDP. Regional study on wood energy today and tomorrow in Asia. Field Document No. 50. Regional Wood Energy Development Program Food and Agricultural Organisation, Bangkok, 1997. p. 168.

[2] Amous S. The role of wood energy in Africa. Tunis/Rome: APEX-ebbd; 1999.

[3] Lefevre T, Todoc JL, Timilsina GR. The role of wood energy in Asia. Bangkok/Rome: Asian Institute of Technology; 1997. p. 107.

[4] Holdren JP, Smith KR. Energy, the environment and health. In: Goldemberg J, editor. World energy assessment. Washington, DC: UNDP; 2000. p. 61-110.

[5] Moreira JR, Goldemberg J. The alcohol programme. Energy Policy 1999;27:229-45.

[6] Turkenburg WC. Renewable energy technologies. In: Goldemberg J, editor. World energy assessment. Washington, DC: UNDP; 2000. p. 220-72.

[7] AEA Technology. Comparison of public acceptability of energy from waste and energy from biomass residues in 5 EU states. Oxfordshire: AEA Technology; 2001. p. 210.

[8] Berndes G, Hoogwijk M, van den Broek R. The contribution of biomass in the future global energy system: a review of 17 studies. Biomass and Bioenergy 2003;25(1): $1-28$.

[9] Lashof DA, Tirpak DA, editors. Policy options for stabilizing global climate. New York, Washington, Philadelphia, London: Hemisphere Publishing Corporation; 1990.

[10] Lazarus M. Towards a fossil free energy future: the next energy transition. Boston: Stockholm Environment Institute; 1993. p. 240.

[11] Johansson TB, Kelly H, Reddy AKN, Williams RH. Renewable fuels and electricity for a growing world economy-defining and achieving the potential. In: Johansson TB, Kelly H, Reddy AKN, Williams RH, 
editors. Renewable energy: sources for fuels and electricity. Washington, DC: Island Press; 1993. p. 1-71.

[12] Fischer G, Schrattenholzer L. Global bioenergy potentials through 2050. Biomass and Bioenergy 2001;20:151-9.

[13] Nakićenović N, Swart R. Special Report on Emission Scenarios. A special report of Working Group III of the Intergovernmental Panel on Climate Change. Cambridge: Cambridge University Press; 2000.

[14] Williams RH. Variants of a low $\mathrm{CO}_{2}$-emitting energy supply system (LESS) for the world-prepared for the IPCC Second Assessment Report Working Group IIa, energy supply mitigation options. Richland: Pacific Northwest Laboratories; 1995. p. 39.

[15] Shell. The evolution of the world's energy system 1860-2060: extracts of a study by Shell International London, 1995.

[16] Sørensen B. Long term scenarios for global energy demand and supply - four global greenhouse mitigation scenarios. Roskilde: Roskilde University; 1999. p. 213.

[17] Hoogwijk M, Faaij A, van den Broek R, Berndes G, Gielen D, Turkenburg WC. Exploration of the ranges of the global potential of biomass for energy. Biomass and Bioenergy 2003;25(2):119-33.

[18] de Vries HJM, Bollen J, Bouwman L, den Elzen M, Janssen M, Kreileman E. Greenhouse-gas emissions in a equity-, environment- and service-oriented world: an IMAGE-based scenario for the next century. Technological Forecasting and Social Change 2000;63(2-3):137-74.

[19] IMAGEteam. The IMAGE 2.2 implementation of the SRES scenarios: a comprehensive analysis of emissions, climate change and impacts in the 21st Century. Bilthoven: National Institute for Public Health and the Environment; 2001.

[20] van Wijk AJM, Coelingh JP. Wind power potential in the OECD countries. Utrecht: Department of Science, Technology and Society, Utrecht University; 1993. p. 35.

[21] World Energy Council. New renewable energy resourcesa guide to the future. London: Kogan Page Limited; 1994. p. 387.

[22] Hoogwijk M, Faaij A, de Vries HJM, Turkenburg WC. Exploration of regional and global cost-supply curves of biomass under four land-use scenarios. Global Environmental Change 2004, submitted for publication.

[23] Fujino J, Yamaij K, Yamamoto H. Biomass-balance table for evaluating bioenergy resources. Applied Energy 1999;63:75-89.

[24] Gielen D, Bos S, de Feber M, Gerlach T. Biomass for greenhouse gas emission reduction. Task 8: optimal emission reduction strategies for Western Europe. Petten: ECN; 2000.

[25] Yamamoto H, Fujino J, Yamaji K. Evaluation of bioenergy potential with a multi-regional global-landuse-and-energy model. Biomass and Bioenergy 2001;21:185-203.

[26] Dessus B, Devin B, Pharabod F. World potential of renewable energies. Paris: CNRS-PIRSEM; 1992. p. 70.
[27] Hall DO, Rosilo-Calle F, Williams RH, Woods J. Biomass for energy: supply prospects. In: Johansson TB, Kelly H, Reddy AKN, Williams RH, editors. Renewable energy: sources for fuels and electricity. Washington, DC: Island Press; 1993 p. 1160.

[28] van den Broek R. Sustainability of biomass electricity systems - an assessment of costs, macro-economic and environmental impacts in Nicaragua, Ireland and the Netherlands. EBURON, Utrecht: Utrecht University; 2000. p. 215.

[29] Williams RH, Larson ED. Advanced gasification-based biomass power generation. In: Johansson TB, Kelly $\mathrm{H}$, Reddy AKN, Williams RH, editors. Renewable energy: sources for fuels and electricity. Washington, DC: Island Press; 1993 p. 1160.

[30] Faaij A, Harmelinck C, Tijmensen M. Long term perspectives for production of fuels from biomass: integrated assessment and R\&D priorities - preliminary results. In: 1st world conference and exhibition on biomass for energy and industry, Sevilla, 2000.

[31] Schulz H. Short history and present trends of FischerTropsch synthesis. Applied Catalysis 1999;186:3-12.

[32] Tijmensen MJA, Faaij A, Hamelinck C, Hardeveld M. Exploration of the possibilities for production of Fischer Tropsch liquids and power via biomass gasification. Biomass and Bioenergy 2002;23(2):129-52.

[33] Lynd LR. Overview and evaluation of fuel ethanol from cellulosic biomass: technology, economics, the environment, and policy. Annual Reviews, Energy Environment 1996;21:403-65.

[34] van Hooijdonk G. Future prospects for ethanol production from ligno-cellulosic biomass. Utrecht: Utrecht University, Copernicus Institute, Department Science and Technology Society; 2002. p. 78.

[35] Alcamo J, Leemans R, Kreileman E. Global change scenarios of the 21 st century-results from the IMAGE 2.1 model. Oxford: Pergamon; 1998. p. 296.

[36] Leemans R, Eickhout B, Strengers B, Bouwman L, Schaeffer M. The consequences of uncertainties in land use, climate and vegetation responses on the terrestrial carbon. Science in China (Series C) 2002;45:126-42.

[37] Leemans R, van den Born GJ. Determining the potential distribution of vegetation, crops and agricultural productivity. In: Alcamo J, editor. IMAGE 2.0-integrated modeling of global climate change. Dordrecht: Kluwer Academic Publishers; 1994.

[38] FAO. Report on the Agro-Ecological Zones project. Methodology and results for South and Central America, vol. 3. Rome: World Soil Resources, Food and Agriculture Organization of the United Nations; 1981.

[39] FAO. FAOSTAT. Agricultural statistics. Available at: www.fao.org. 2003.

[40] FAO. Agriculture: towards 2015/2030 - technical interim report. Rome: FAO; 2000.

[41] Luyten JC. Sustainable world food production and environment. Wageningen: AB-DLO Delft Hydraulics; 1995. 
[42] Leach G. Global land \& food in the 21st century-trends $\&$ issues for sustainability. Stockholm: Stockholm Environmental Institute; 1995. p. 90.

[43] Rosegrant MW, Paisner MS, Meijer S, Witcover J. 2020 global food outlook. Washington, DC: IFPRI; 2001. p. 18.

[44] Döös BR, Shaw R. Can we predict the future food production? A sensitivity analysis. Global Environmental Change 1999;9(4):261-83.

[45] van den Broek R, van Wijk A, Turkenburg WC. Farmbased versus industrial eucalyptus plantations for electricity generation in Nicaragua. Biomass and Bioenergy 2000;19(5):295-310.

[46] Perlack RD, Wright L, Huston MA, Schramm WE. Biomass fuel from woody crops for electric power generation. Washington: ORNL; 1995.

[47] Rosenquist H, Roos A, Ling E, Hektor B. Willow growers in Sweden. Biomass and Bioenergy 2000;18(2):137-45.

[48] Silva de la Maza P. Personal communication. Chichigalpa: Project leader Forestry Project San Antonio; 1998.

[49] Kgathi DL, Sekhwela MBM. Southern Africa's savannas: sustainable management of natural resources. Botswana: University of Botswana; 1998. p. 15.

[50] World Commission on Protected Areas (WCPA). Protected areas: benefits beyond boundaries-WCPA in action. Gland: IUCN; 2000. p. 19.

[51] Kemp-Benedict E, Heaps C, Raskin P. Global scenarios group futures-technical notes. Stockholm: Stockholm Environmental Institute, Global Scenario Group; 2002. p. 264.

[52] German Advisory Council on Global Change (WBGU). World in transition - conservation and sustainable use of the biosphere. Bremerhaven: WBGU; 1999. p. 441.

[53] United Nations Population Division: Department of Economic and Social Affairs. World urbanization prospects: the 2001 revision. New York: United Nation; 2002. p. 318.

[54] UNEP. Global Environmental Outlook 3. London: UNEP, Earthscan; 2002. p. 416.

[55] Bouwman AF, Van der Hoek KW, Eickhout B, Soenario I. Exploring changes in world ruminant production systems. Agricultural Systems 2005;84(2):121-53.

[56] FAO. World livestock production systems. Current status, issues and trends. Rome: Food and Agricultural Organisation; 1996. p. 83.
[57] Vleeshouwers LM. Yield increases of biomass energy crops: a look to the future. In: Proceedings of the sustainable energy-new challenges for agriculture and implications for land use. Wageningen: Wageningen University; 2000.

[58] Hoogwijk M. Crop modelling of eucalyptus plantations in Nicaragua. Utrecht: Department of Science, Technology and Society; 1998. p. 31.

[59] Goldemberg J. World energy assessment. New York: United Nations Development Programme, United Nations Department of Economic and Social Affairs, World Energy Council; 2000. p. 508.

[60] Dornburg V, Faaij A. Efficiency and economy of woodfired biomass energy systems in relation to scale regarding heat and power generation using combustion and gasification technologies. Biomass and Bioenergy 2001;21:91-108.

[61] Faaij A, Meuleman B, Ree RV. Long term perspectives of biomass integrated gasification/combined cycle (BIG/CC) technology: costs and efficiency and a comparison with combustion. Utrecht: Department of Science, Technology and Society, Utrecht University; 1998. p. 93.

[62] Hamelinck C, Faaij A, den Uil H, Boerrigter $H$. Production of FT transportation fuels from biomass; technical options, process analysis and optimisation and development potential. Energy 2004;29(11):1743-71.

[63] Swisher J, Wilson D. Renewable energy potentials. Energy 1993; 18(5):437-59.

[64] Berndes G. Bioenergy and water-the implications of large-scale bioenergy production for water use and supply. Global Environmental Change 2002;12:253-71.

[65] Wirsenius S. Human use of land and organic materialsmodelling the turnover of biomass in the global food system. Göteborg: Chalmers University; 2000. p. 255.

[67] IEA and OECD. OECD balances of non-OECD countries 1999-2000. Paris: IEA/OECD; 2001.

\section{Further reading}

[66] Yamamoto H, Yamaij K, Fujino J. Evaluation of bioenergy resources with a global land use and energy model formulated with SD technique. Applied Energy 1999;63:101-13. 